\title{
Structural and rheological evolution of the Laramide subduction channel in southern California
}

\author{
Haoran Xia and John P. Platt \\ Department of Earth Sciences, University of Southern California, Los Angeles, CA 90089-0740, USA \\ Correspondence to: Haoran Xia (haoranxi@usc.edu)
}

Received: 22 October 2016 - Discussion started: 26 October 2016

Revised: 2 March 2017 - Accepted: 8 March 2017 - Published: 30 March 2017

\begin{abstract}
The Pelona Schist in the San Gabriel Mountains, southern California, formed in the Laramide subduction channel, exhibits multiple phases of deformation/metamorphism and provides valuable insights into the rheological properties of the subduction channel. Petrological and microstructural analysis indicates that the Pelona Schist has undergone three major deformational/metamorphic events. Subduction of volcanic and sedimentary protoliths during D1 was recorded by aligned mineral inclusions in albite and epidote porphyroblasts. Metamorphic temperature and pressure at the end of subduction yielded by Raman spectroscopy of carbonaceous material and phengite barometry were $519 \pm 20^{\circ} \mathrm{C}$ and $10.5 \pm 0.4$ kbar, respectively. During D1 the dominant deformation mechanism was quartz pressure solution, and the estimated shear stress at the end of D1 was less than $10 \mathrm{MPa}$. D2, the first stage exhumation of the Pelona Schist along the upper section of the subduction channel during return flow, was recorded by retrogressive metamorphism, isoclinal folding, and a pervasive schistosity that wraps around earlier porphyroblasts. Metagreywacke was deformed mainly by quartz pressure solution and metachert was deformed dominantly by dislocation creep during D2. The shear stress in metagreywacke was less than $10 \mathrm{MPa}$ and that in metachert was between $8.3+2.7 /-1.5$ and $12.9+.9 /-2.3 \mathrm{MPa}$, resulting in a strain rate of $1.4 \times 10^{-13}$ to $5.5 \times 10^{-13} \mathrm{~s}^{-1}$. A topography driven model is proposed as the main driving force of D2 exhumation. D3 records normal-sense movement on the Vincent Fault, which separates the schist from overlying arc and continental basement. This resulted in the second stage of exhumation, creating a major synform and associated mylonitic fabric in the upper section of the Pelona Schist. Conditions at the beginning of D3 were $390 \pm 13{ }^{\circ} \mathrm{C}$ and $5.8 \pm 0.8 \mathrm{kbar}$
\end{abstract}

given by the TitaniQ thermometer and phengite geobarometer. The deformation was dominated by quartz dislocation creep with a strain rate of $4.5 \pm 1.2 \times 10^{-13} \mathrm{~s}^{-1}$ at a shear stress of $20.1+7.3 /-4.0 \mathrm{MPa}$.

\section{Introduction}

Sedimentary and volcanic materials lying on subducting plates are commonly carried down and deformed within a subduction channel between the two plates (Cloos and Shreve, 1988; Gerya and Stockhert, 2002). Some of this material may be exhumed after experiencing high-pressure, lowtemperature metamorphism. Various models have been proposed to interpret the burial and exhumation cycle of highpressure subduction complexes in accretionary settings (e.g., Brandon et al., 1998; Brun and Faccenna, 2008; Platt, 1986; Ring et al., 2007). The best way to test these models is to examine the deformational and metamorphic history of rocks exhumed from the subduction channel.

The rheological properties of subduction channels may place controls on the interaction of the converging plates, such as depth of seismicity (e.g., Ruff and Tichelaar, 1996) and coupling of the plates (e.g., Stöckhert, 2002). Geophysical observations cannot easily yield the mechanical properties of the plate interface in active subduction zones (Grigull et al., 2012; but see Houston, 2015). The only directly available information on small-scale deformation mechanisms, stress states and material strength along the plate interface comes from the rocks exhumed from a subduction zone (e.g., Wassmann and Stöckhert, 2013).

The Pelona Schist in the Transverse Ranges, southern California, was formed during the Late Cretaceous-Paleocene 
Laramide subduction event, and it is an ideal case to scrutinize the subduction zone. In this paper we first construct the deformational and metamorphic history of Pelona Schist by employing multiple thermobarometers and zircon fission track analysis, then decipher the exhumation mechanism of the Pelona Schist, and finally we infer deformation mechanisms and rheological properties including stresses and temperatures along the subduction channel during the different deformation stages.

\section{Geologic background}

Laramide subduction caused eastward migration of magmatic activity in western North America from Late Cretaceous to early Tertiary time; this, together with basementinvolved thrusting in the Laramide foreland, led to the idea that this was a period of flat-slab subduction (Coney and Reynolds, 1977; Dickinson and Snyder, 1978). Although debates exist (e.g., Barth and Schneiderman, 1996; Ehlig, 1981), it is widely accepted that the Pelona, Orocopia, and Rand schists and the schists of Portal Ridge and Sierra de Salinas in southern California and adjacent areas are products of this subduction event (e.g., Burchfiel and Davis, 1981; Crowell, 1981; Grove et al., 2003; Hamilton, 1988; Jacobson et al., 2007), and that their protolith ages decrease from northwest to southeast (Grove et al., 2003). These ocean-affiliated schists were metamorphosed under moderately high-pressure conditions from blueschist facies to amphibolite facies beneath the Cordilleran Mesozoic magmatic arc, and generally preserve retrograde metamorphic textures (e.g., Chapman et al., 2010; Jacobson and Dawson, 1995; Kidder and Ducea, 2006).

Nowadays the schists are separated from the upper plate of Precambrian to Mesozoic igneous and metamorphic rocks by normal faults. For the Rand Schist and the schist of Sierra de Salinas, Chapman et al. (2010) suggested that the contact between the schists and the upper plate was remobilized as a normal fault during exhumation even though it was proximal to the original subduction megathrust. In the Orocopia Mountains, Jacobson and Dawson (1995) interpreted the upper boundary of the Orocopia schist as an early Miocene low-angle detachment fault, underlain by a thin zone of mylonitized and retrogressed schist. However, the Vincent Fault above the Pelona Schist, which is also known as the "Vincent thrust", was argued to be the original subduction zone megathrust (Ehlig, 1981; Jacobson et al., 1996).

The Pelona Schist occurs in the Sierra Pelona and in the eastern San Gabriel Mountains of the Transverse Ranges (Fig. 1); we focus on the latter in this paper because of the outstanding exposures along the East Fork of the San Gabriel River. The Pelona Schist in the East Fork area is separated by the regionally gently SW-dipping Vincent Fault from a Meso-Proterozoic gneiss complex and Mesozoic granitoid rocks in the hanging wall (Fig. 2), which formed part of the

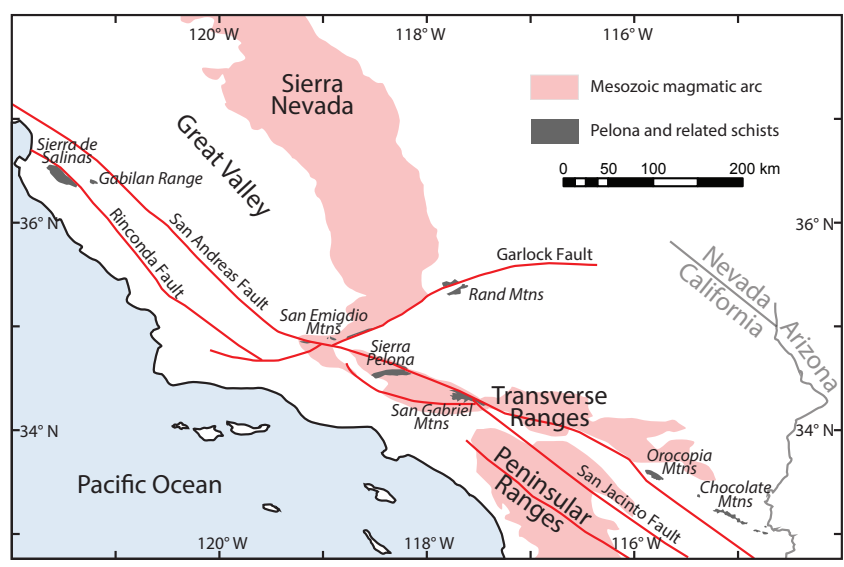

Figure 1. Regional tectonic map of southern California showing outcrops of Laramide subduction related schists, Mesozoic magmatic arc, and major faults. Modified from Jennings (1977).

Mesozoic arc in California. A striking feature of the Pelona Schist is the complete lack of intrusive rocks related to the Late Cretaceous arc that directly overlies the Vincent Fault. A mylonite zone is developed in the lower 500 to $1000 \mathrm{~m}$ of the hanging wall. The Pelona Schist in the East Fork area occurs in the core of a NW-trending post-metamorphic antiform (Jacobson, 1997), and is truncated to the NE by the Punchbowl and San Andreas faults (Dibblee, 1967). Through the approximately $4 \mathrm{~km}$ thick transect in the East Fork, the Pelona Schist consists of $\sim 90 \%$ metagreywacke, $\sim 10 \%$ mafic greenschist and a minor amount of metachert (Jacobson, 1997), all of which were metamorphosed under highpressure greenschist facies conditions. The peak pressure and temperature were constrained in the Sierra Pelona at up to $10 \pm 1 \mathrm{kbar}$ and $620-650^{\circ} \mathrm{C}$ (Graham and Powell, 1984). An inverted thermal gradient in the Pelona Schist was reported both in the Sierra Pelona (Graham and Powell, 1984) and in the East Fork of the San Gabriel Mountains (Jacobson, 1983a, 1995). The protolith of the Pelona Schist has a maximum age of $68 \mathrm{Ma}$ based on detrital zircon ${ }^{206} \mathrm{~Pb} /{ }^{238} \mathrm{U}$ dating (Grove et al., 2003). Amphibole ${ }^{40} \mathrm{Ar} /{ }^{39} \mathrm{Ar}$ ages from mafic schist in the East Fork are $60.3 \pm 2.6$ and $58.9 \pm 2.5 \mathrm{Ma}$ (Jacobson, 1990), and white mica ${ }^{40} \mathrm{Ar} /{ }^{39} \mathrm{Ar}$ ages cluster between 55.5 and $60.8 \mathrm{Ma}$ (Grove et al., 2003; Jacobson, 1990) though one metagreywacke sample from the deepest structural level yields a white mica ${ }^{40} \mathrm{Ar} /{ }^{39} \mathrm{Ar}$ age of $31.7 \pm 0.2 \mathrm{Ma}$. To improve the precision of cooling history of the Pelona Schist, in this study we also performed zircon fission track analyses as presented in Sect. 5.4.

A phase of Miocene magmatic activity in the East Fork area is characterized by intermediate dykes and sills in both the upper plate and the Pelona Schist, as well as a dacite sill complex with a cumulative thickness of a few tens of meters parallel to the main schistosity of the Pelona Schist near Iron Fork, which was dated at 14-16 Ma by the K/Ar method (Miller and Morton, 1977). 

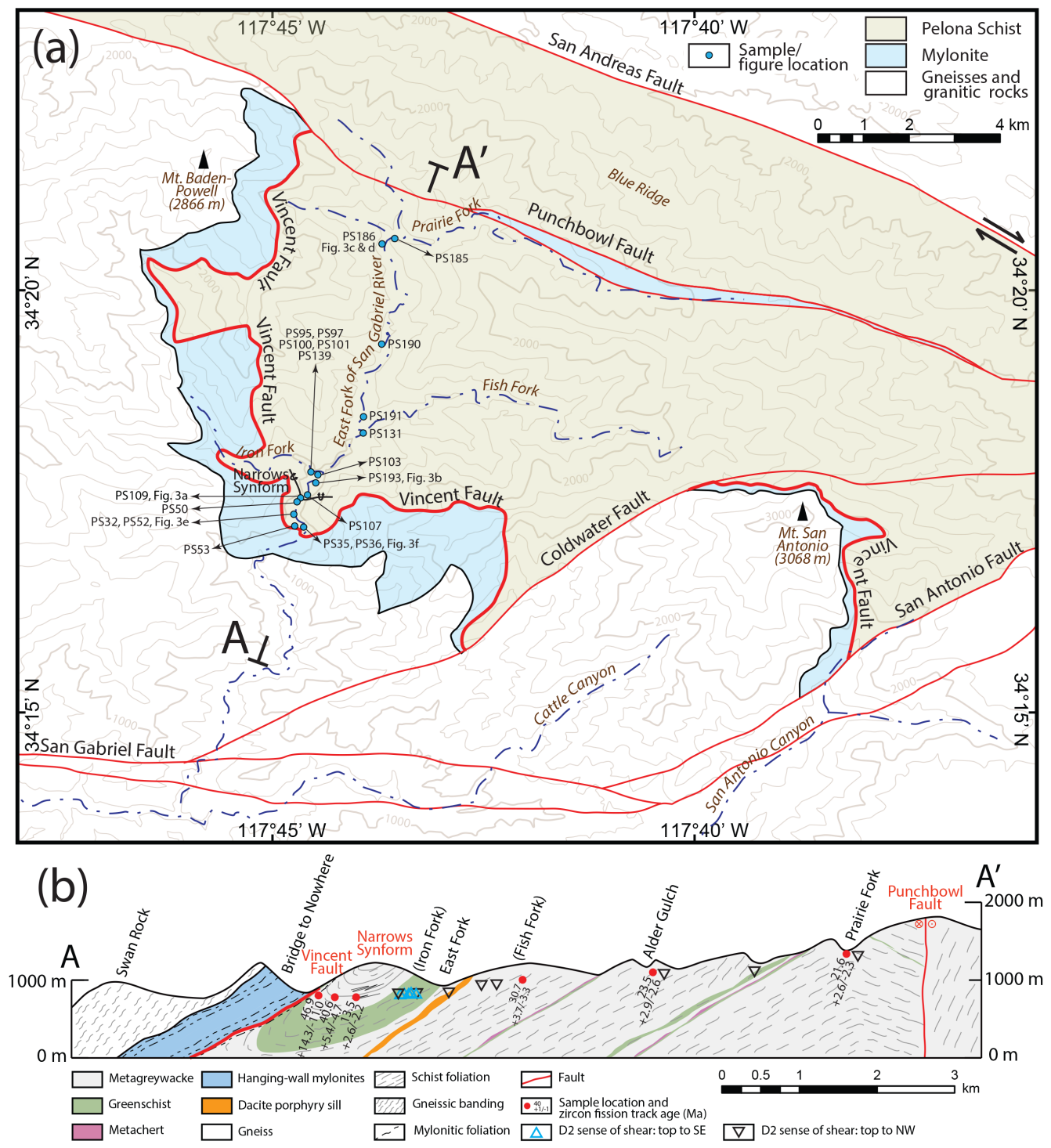

Figure 2. (a) Geologic map of eastern San Gabriel Mountains. Modified from Dibblee (2002a, b, c, d). The background topographic map is adapted from the 1:100000-scale Metric Topographic Map of San Bernardino, California, compiled and published by the United States Geological Survey in 1982. Contour interval of $200 \mathrm{~m}$. (b) Cross section of A-A' in panel (a).

\section{Methods}

\subsection{Thermobarometers}

\subsubsection{Raman spectroscopy on carbonaceous material $(\mathbf{R S C M})$}

Organic material in rocks undergoes irreversible graphitization during prograde metamorphism, and the degree of this transformation is a function of temperature and is not subject to retrogression, so the temperature measured by this approach approximates the maximum temperature (Beyssac et al., 2002). The degree of organization of carbonaceous material can be measured using Raman microspectroscopy by cal- culating ratios of the peak areas at bands of 1350,1580 , and $1620 \mathrm{~cm}^{-1}$. The calibration used here (Beyssac et al., 2002) comes with a maximum error of $\pm 50^{\circ} \mathrm{C}$, stemming from the uncertainties in the thermobarometric methods used to calibrate it. The precision of the method, however, is $\sim 10^{\circ} \mathrm{C}$ (Beyssac et al., 2002). RSCM measurements of carbon-rich metagreywacke samples were completed with a $514 \mathrm{~nm}$ argon laser in the Mineral Microspectroscopy Facility at the California Institute of Technology, and the spectra were processed with the software Peakfit following the procedure outlined in Beyssac et al. (2002). 


\subsubsection{Quartz $c$ axis fabric opening-angle thermometer}

The empirical quartz $c$ axis fabric opening-angle thermometer (Kruhl, 1998) utilizes the linear relationship between the opening angle of quartz $c$ axis fabric and the temperature during fabric formation. This deformation-related thermometer has an uncertainty of $\pm 50^{\circ} \mathrm{C}$, and is applicable for rocks deformed in the $\sim 300-650{ }^{\circ} \mathrm{C}$ range. $\mathrm{Kruhl}(1998)$ noticed that at given temperatures, the opening angles of quartz $c$ axis fabrics from experimentally deformed rocks at high strain rates are smaller than those from naturally deformed rocks, but he argued that strain rate should not affect the thermometer when applied to rocks deformed at natural conditions because the thermometer was established on rocks deformed at natural strain rates. By promoting prism [c] slip, high water content may result in larger opening angles of fabrics, but the direct link between water content and opening angle of quartz fabric has not yet been demonstrated experimentally (Law, 2014). Quartz fabrics, or crystallographic preferred orientations (CPOs), were measured and analyzed using a Hikari electron backscatter diffraction (EBSD) detector mounted on a JEOL-7001F scanning electron microscope at the Center for Electron Microscopy and Microanalysis, University of Southern California, and associated OIM collection/analysis software developed by EDAX. The acceleration voltage was $25 \mathrm{kV}$, the working distance $15 \mathrm{~mm}$, and the step size half of the pre-estimated average grain size.

\subsubsection{Titanium-in-quartz thermobarometer (TitaniQ)}

The substitution of Si by Ti in quartz is $P$ and $T$ dependent, and it enables $P-T$ estimation by measuring titanium content in quartz (Thomas et al., 2010; Wark and Watson, 2006) and combining the results with an independent thermobarometer. In this study we combined TitaniQ with the phengite geobarometer. Calibrations were performed at constant pressure (Wark and Watson, 2006) and varying pressure conditions (Thomas et al., 2010) by synthesizing quartz and rutile from silica-saturated aqueous fluids. The uncertainty in the temperature determined using the calibration of Thomas et al. (2010) is approximately $\pm 20^{\circ} \mathrm{C}$ if the error of the independently constrained pressure is $\pm 1 \mathrm{kbar}$. Huang and Audétat (2012) determined an alternative calibration by assuming that their lowest $\mathrm{Ti}$ concentration measurements were closest to equilibrium. Thomas et al. (2015) evaluated the published calibrations by synthesizing and then recrystallizing quartz at different $P-T$ conditions, and confirmed the validity of the calibration of Thomas et al. (2010), which we used in this study. Samples were first examined by cathodoluminescence imaging using a Tescan Vega-3 XMU scanning electron microscope at University of California, Los Angeles, and were then measured on a Cameca IMS 6f secondary ion mass spectrometer (SIMS) at Arizona State University. SIMS settings and analytical procedures followed those given by Behr et al. (2011).

\subsubsection{Phengite geobarometer}

The composition of the muscovite-celadonite solid solution series is a function of pressure and temperature. Substitution of celadonite for muscovite, resulting in higher Si content, is favored by increasing pressure and decreasing temperature, based on which Massonne and Schreyer (1987) established a phengite geobarometer. The calibration is based on independent $P-T$ estimates from coexisting mineral assemblages, and is subject to large uncertainties. Mineral analyses were performed on a JEOL JXA-8200 electron microprobe at University of California, Los Angeles. The acceleration voltage was $15 \mathrm{kV}$, the beam current $10 \mathrm{nA}$, and the beam diameter 5-8 $\mu \mathrm{m}$.

\subsection{Recrystallized grain size piezometry for quartz}

\subsubsection{Grain size measurement}

Grain boundaries were manually traced on the optical photomicrographs and then the grain size was measured in ImageJ. The grain size is defined as the diameter of a circle with the same area as the grain in thin section. The average 2-D grain size of recrystallized quartz grains in a sample is calculated as the root mean square (RMS) diameter of all the measured grains in this sample. No stereological correction was applied in order to keep consistent with the piezometer calibration (Stipp and Tullis, 2003). The grain sizes are reported with 1 standard deviation. Thin sections used for grain size measurement were cut normal to foliation and parallel to lineation.

\subsubsection{Stress calculation}

Differential stress was calculated using quartz recrystallized grain size piezometer $D=10^{3.56 \pm 0.27} \times \sigma^{-1.26 \pm 0.13}$, where $D$ is the grain size of recrystallized quartz in microns and $\sigma$ is the differential stress in megapascals (Stipp and Tullis, 2003). Differential stress calculated from the previous equation was multiplied by a factor of 0.73 to correct for possible errors in the stress measurements on the Griggs-type apparatus used for the original calibration (Holyoke and Kronenberg, 2010). The piezometer can be applied to quartz recrystallized grain size up to $120 \mu \mathrm{m}$ (Stipp et al., 2010). Within uncertainties, the piezometer is independent of the water content of the quartz, temperature, and the quartz alpha-beta phase transition (Stipp et al., 2006). Shear stress in a plane stress setting was calculated from differential stress by dividing by $\sqrt{3}$ (Behr and Platt, 2013).

\subsection{Quartz shape preferred orientation}

Digital polarized-light photomicrographs were taken and then the grain boundaries of quartz were traced. The graphs of quartz grain boundaries were processed by ImageJ to mea- 
sure the orientation of grain long axes. The results were presented in rose diagrams plotted by MATLAB.

\subsection{Detrital zircon fission track analysis}

Detrital zircon fission track analysis was performed on six metagreywacke samples by Apatite to Zircon, Inc. The zircon grains were mounted, etched and polished for optical analysis following the procedure outlined in Moore et al. (2015). The U content was measured using Agilent 7700x LA-ICP-MS mounted with a Resonetics RESOlution M-50 laser ablation system.

\section{Deformation history of the Pelona Schist in the eastern San Gabriel Mountains}

The Pelona Schist in the San Gabriel Mountains consists mainly of metagreywacke (Fig. 3a) with minor amounts of mafic greenschist (Fig. 3b) and metachert (Fig. 3c), all of which were metamorphosed up to high-pressure greenschist facies. The typical mineral assemblage of metagreywacke is albite + quartz + white mica + chlorite + stilpnomelane + epidote + sphene with garnet grains and graphitized carbonaceous material preserved within the albite porphyroblasts. The composition of garnet changes from spessartine rich in the core to grossular rich in the rim (Jacobson, 1983a). Mafic greenschist is made up of amphibole + albite + chlorite + epidote + quartz + sphene. Amphibole here is actinolite to actinolitic hornblende with high $\mathrm{Na} / \mathrm{Al}$ ratio (Jacobson, 1997). Metachert consists of quartz and minor amounts of white mica, stilpnomelane, albite, garnet, sodic amphibole, and piemontite. Calcite can be found in all three rock types. Boudinaged quartz veins are common in greenschist.

The earliest fabric (S1) in the Pelona Schist is preserved as straight inclusion trails in albite porphyroblasts in metagreywacke, and in albite and epidote porphyroblasts in greenschist (see Sect. 4.2, below). The dominant deformational structure in the Pelona Schist is folding of the compositional layering (Fig. 3a, c, d and e). Two types of the folds have been recognized in the field: (1) pervasive tight isoclinal folds (Fig. 3a, c and d) and (2) the large-scale Narrows synform and associated minor folds (Fig. 3e). Isoclinal folds occur pervasively in the East Fork transect, and are characterized by their tightly closed limbs with a length varying from less than a meter to a few tens of meters. SW-dipping axial-planar schistosity (S2) is well developed. Sheath folds (Fig. 3d) and axis-parallel stretching lineation indicate SE-NW stretching. The Narrows synform and associated minor folds occurred in the upper $700 \mathrm{~m}$ section of the Pelona Schist and refold the isoclinal folds. The Narrows synform is more open, but its hinge is generally parallel to those of the isoclinal folds. Moderate SW-dipping axial-planar crenulation cleavage (S3) is developed in the Narrows synform. The overturned upper limb of the Narrows synform is cut by the Vincent Fault. Both
$\mathrm{S} 2$ and $\mathrm{S} 3$ are moderately SW dipping, and the pervasive subhorizontal stretching lineation trends SE.

\subsection{Microstructures}

\subsubsection{D1 fabrics}

$\mathrm{S} 1$ is preserved by the trails of mineral inclusions in albite porphyroblasts in metagreywacke (Fig. 4a), and in epidote and albite porphyroblasts in greenschist (Fig. 4b). The mineral inclusions are white mica, epidote, quartz, garnet, zircon and abundant carbonaceous material. Some of the trails are rich in carbonaceous material or mica, while others are rich in quartz, which defines a differentiated cleavage. Orientation of S1 varies from one porphyroblast to another. Quartz in $\mathrm{S} 1$ has a grain size ranging from 10 to $50 \mu \mathrm{m}$ and shows a random CPO (Fig. 4c). No undulose extinction or recrystallization was observed in quartz inclusions.

\subsubsection{D2 fabrics}

The Pelona Schist exhibits ductile deformation during D2, and no pseudotachylite concordant with S2 was found in the Pelona Schist.

\section{Metagreywacke}

Rims of some albite porphyroblasts are free of inclusions, which probably resulted from post-D1 overgrowth. Albite does not show recrystallization or undulose extinction. A few albite grains were broken apart with quartz deposited in between (Fig. 5a). White mica and chlorite are strongly differentiated into phyllosilicate-rich domains, or $P$ domains (Shelley, 1993), and define S2 (at top of Fig. 5b), which wraps around the albite porphyroblasts. In the hinges of isoclinal folds, the trails of minerals included in albite (S1) were crenulated (Fig. 4d), which might represent an early stage in the development of S2, prior to the growth of albite.

Quartz crystals in quartz-rich domains, or $Q$ domains (Shelley, 1993), and in strain shadows around albite and epidote porphyroblasts, are equant and coarse-grained (100 to $200 \mu \mathrm{m}$ ), with trails of fluid inclusions and relatively straight grain boundaries, though bulging occurs in some crystals (Fig. 5b, c and d). They show undulose extinction. Quartz crystals in $P$ domains have a large aspect ratio (more than 2) and a grain size of $\sim 30$ to $100 \mu \mathrm{m}$ (Fig. $5 \mathrm{~b}$ and c).

Shear sense indicators are not common in the metagreywacke. Shear bands and asymmetric albite porphyroblasts are the only two types of shear sense indicators found in the samples from north of Iron Fork, in the structurally deepest part of the schist. They show a top-to-NW sense of shear (Fig. 5e). In the Iron Fork area, conjugate shear bands are observed and no consistent shear sense can be inferred (Fig. 5f). In samples south of Iron Fork, S2 has been overprinted by S3 and its sense of shear cannot be inferred. 

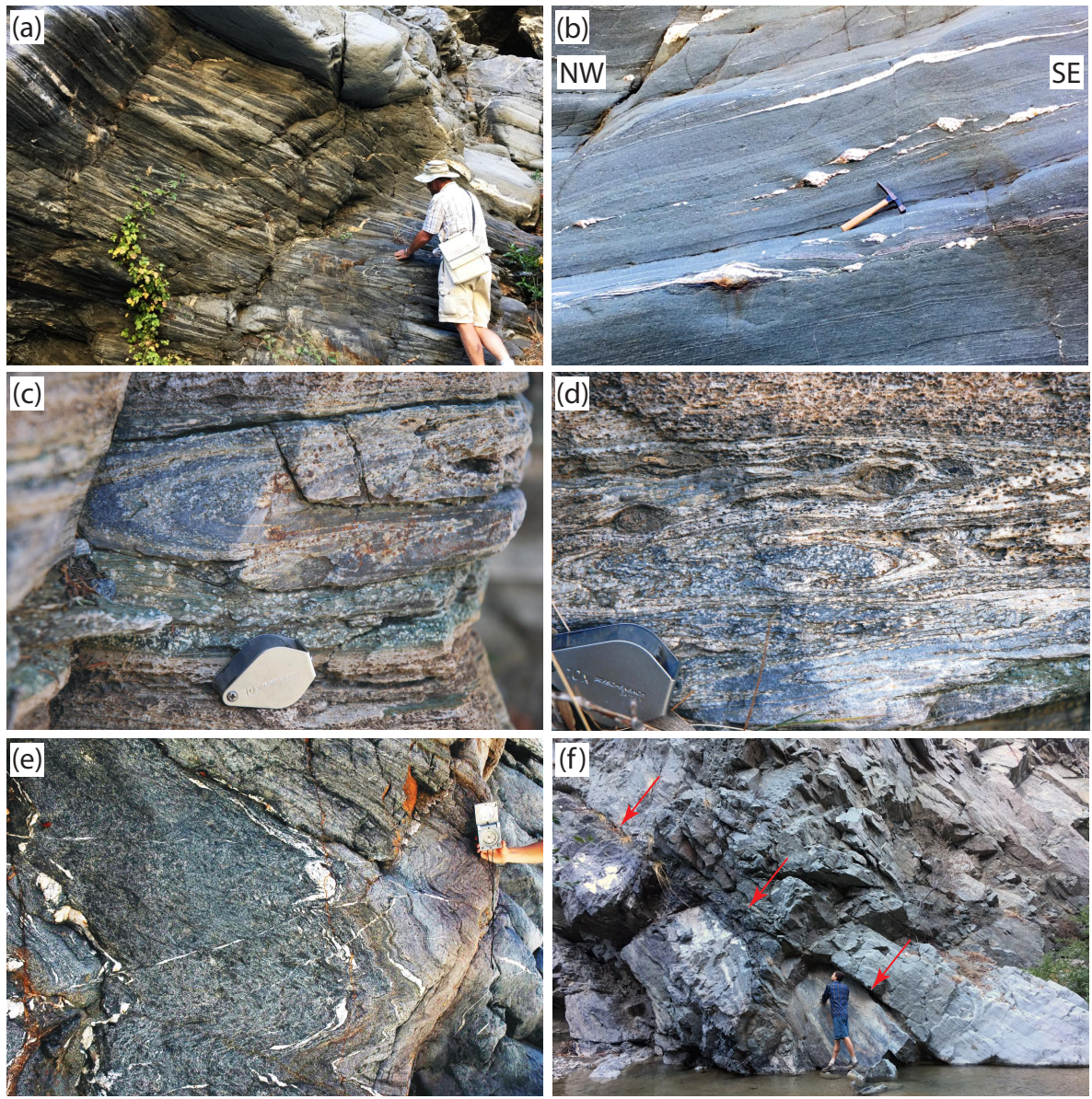

Figure 3. Outcrops of Pelona Schist. Photo locations can be found in Fig. 2a and Table S1. (a) D2 folds in metagreywacke. (b) Mafic greenschist with boudinaged quartz veins. (c) D2 folds in metachert. (d) Sheath folds in metachert and mafic greenschist. (e) Minor D3 folds near the hinge of the Narrows synform. (f) Vincent Fault as shown by the arrows; viewing SE.

\section{Metachert}

Quartz grains exhibit equant grain shape and relatively straight grain boundaries, which may be pinned by oriented white mica. Most quartz grains show weak undulose extinction, and deformation lamellae occur in a few cases. In the structurally lowest level near Prairie Fork, the grain size ranges from 100 to $300 \mu \mathrm{m}$ and the average is $136 \pm 47 \mu \mathrm{m}$ (Fig. 6a). In samples from Fish Fork and Iron Fork that were not strongly annealed, quartz shows evidence of recrystallization by subgrain rotation and/or grain boundary migration (Fig. 6b). The average recrystallized grain size varies between $47 \pm 14$ and $82 \pm 25 \mu \mathrm{m}$ (Table 1). Quartz $c$ axis pole figures of samples close to Prairie Fork exhibit maxima around the $z$ axis and a sub-maximum near the $y$ axis (Fig. 6c), while samples near Iron Fork show discontinuous to continuous crossed girdles (Fig. 6d).

Sense of shear in metachert can be inferred from quartz $c$ axis pole figures and shear bands. For rocks north of (structurally below) Iron Fork, the quartz CPO of a Prairie Fork sample appears to be symmetrical (Fig. 6c) and the shear bands of a Fish Fork sample show a top-to-NW sense of shear (Fig. 6e). For rocks south of (structurally above) Iron Fork, quartz recrystallized grain shape fabric and CPOs show a consistent top-to-SE sense of shear (e.g., Fig. 6b, d and f).

\section{Greenschist}

Chlorite, actinolite, tabular albite and epidote define S2 (Fig. 7a and b). As in the metagreywacke, albite in greenschist also exhibits evidence of overgrowth (Fig. 7c). Quartz is concentrated in strain shadows around epidote porphyroblasts or magnetite (Fig. 7d). Most of the quartz is recrystallized by grain boundary migration or subgrain rotation.

\subsubsection{D3 fabric}

$\mathrm{S} 3$ is best preserved in the metagreywacke in the hinge and upper limb of the Narrows synform; the S2 foliation was strongly crenulated, and the axial planes of the crenulation define S3 (Fig. 8a). 

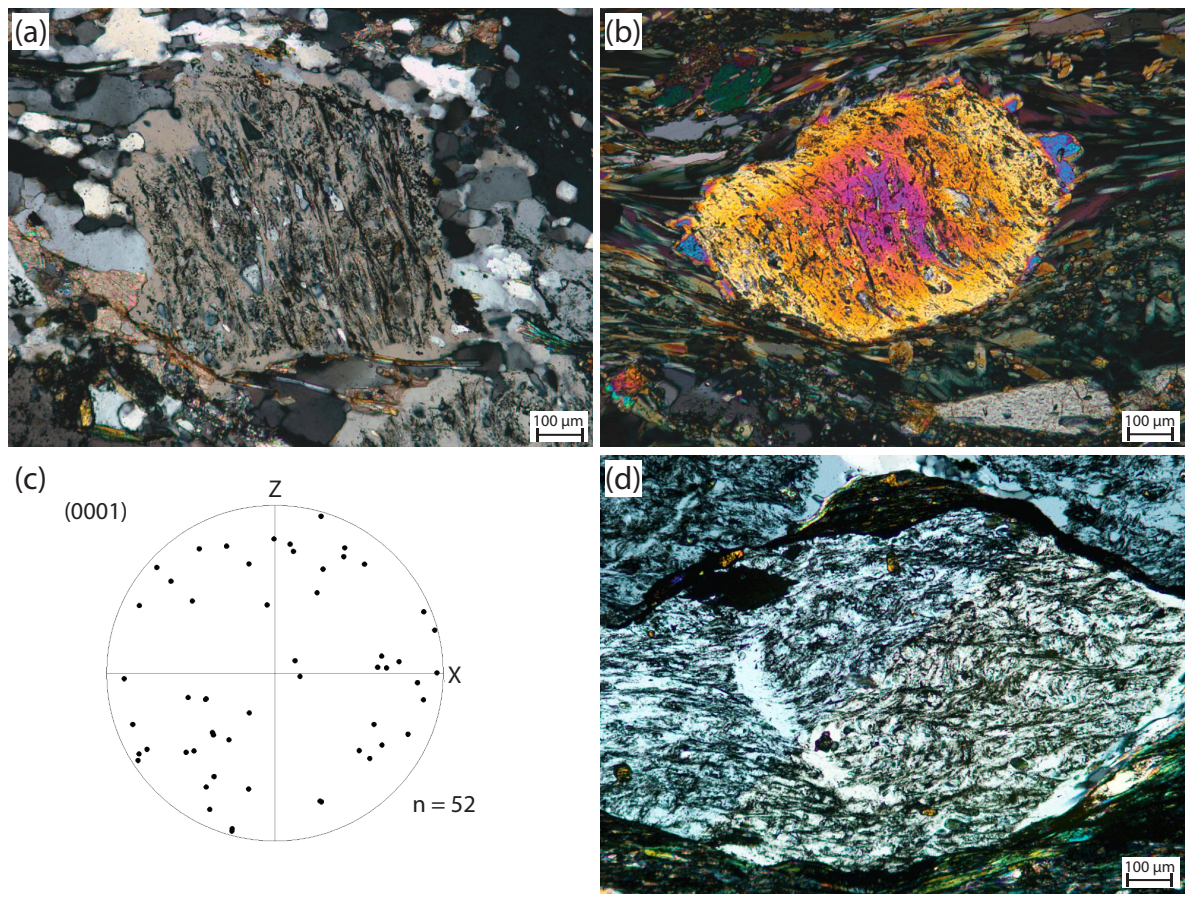

Figure 4. S1 fabric in metagreywacke and greenschist. See Fig. 2a and Table S1 for sample locations. (a) The mineral inclusions in albite outline S1. Note the differentiated cleavage. Sample PS52. (b) S1 in mafic greenschist shown by the mineral inclusions in the epidote porphyroblast. Sample 95. (c) CPO of quartz inclusions in one albite porphyroblast in Sample PS52. (d) S1 in albite grains is crenulated as shown by the trails of graphite. Sample PS109.

Table 1. Stress estimates.

\begin{tabular}{lllrrrr}
\hline Domain & Sample no. & Rock type & $\begin{array}{r}\text { Recrystallized } \\
\text { grain size }(\mu \mathrm{m})\end{array}$ & $\begin{array}{r}\text { no. of } \\
\text { grains }\end{array}$ & $\begin{array}{r}\text { Differential stress } \\
(\mathrm{MPa})\end{array}$ & $\begin{array}{r}\text { Shear stress } \\
(\mathrm{MPa})\end{array}$ \\
\hline S3 & PS35 & Metagreywacke & $28 \pm 9$ & 63 & $34.8+12.7 /-7.0$ & $20.1+7.3 /-4.0$ \\
S2 & PS106 & Metachert & $85 \pm 25$ & 78 & $14.3+4.6 /-2.7$ & $8.3+2.7 /-1.5$ \\
S2 & PS98 & Metachert & $49 \pm 14$ & 123 & $22.4+6.7 /-4.0$ & $12.9+3.9 /-2.3$ \\
S2 & PS96 & Metachert & $54 \pm 17$ & 249 & $20.6+7.3 /-4.1$ & $11.9+4.2 /-2.3$ \\
S2 & PS140 & Metachert & $63 \pm 16$ & 93 & $18.3+4.7 /-3.0$ & $10.6+2.7 /-1.7$ \\
S2 & PS131 & Metachert & $61 \pm 23$ & 195 & $18.7+8.5 /-4.2$ & $10.8+4.9 /-2.4$ \\
S2 & PS191 & Metagreywacke & $74 \pm 17$ & 95 & $16.1+3.8 /-2.5$ & $9.3+2.2 /-1.4$ \\
S2 & PS188 & Metagreywacke & $80 \pm 19$ & 42 & $15.1+3.8 /-2.4$ & $8.7+2.2 /-1.4$ \\
S2 & PS187 & Metachert & $70 \pm 22$ & 92 & $16.8+6.0 /-3.3$ & $9.7+3.4 /-1.9$ \\
\hline
\end{tabular}

In the upper limb of the Narrows synform, quartz is completely recrystallized by subgrain rotation (SGR), and the recrystallized grain size clusters around $30 \mu \mathrm{m}$. Noticeably, some of the grain boundaries of the recrystallized quartz grains show an irregular shape due to bulging, forming finegrained quartz crystals (Fig. 8b). Albite remains intact and does not show any evidence of plastic deformation.

The top $\sim 100 \mathrm{~m}$ of the Pelona Schist immediately beneath the Vincent Fault exhibits strong mylonitic microstructure. Quartz grains have been completely recrystallized by SGR, showing a recrystallized grain shape fabric and indicating a top-to-SE sense of shear. The grain size of recrystallized quartz is around $18 \mu \mathrm{m}$ (Fig. 8c). In thin sections cut perpendicular to the lineation, axial planes of white mica crenulations are parallel to the shape preferred orientation of recrystallized quartz (Fig. 8d). This suggests that crenulation of white mica due to the Narrows synform was coeval with mylonitization along the Vincent Fault. 

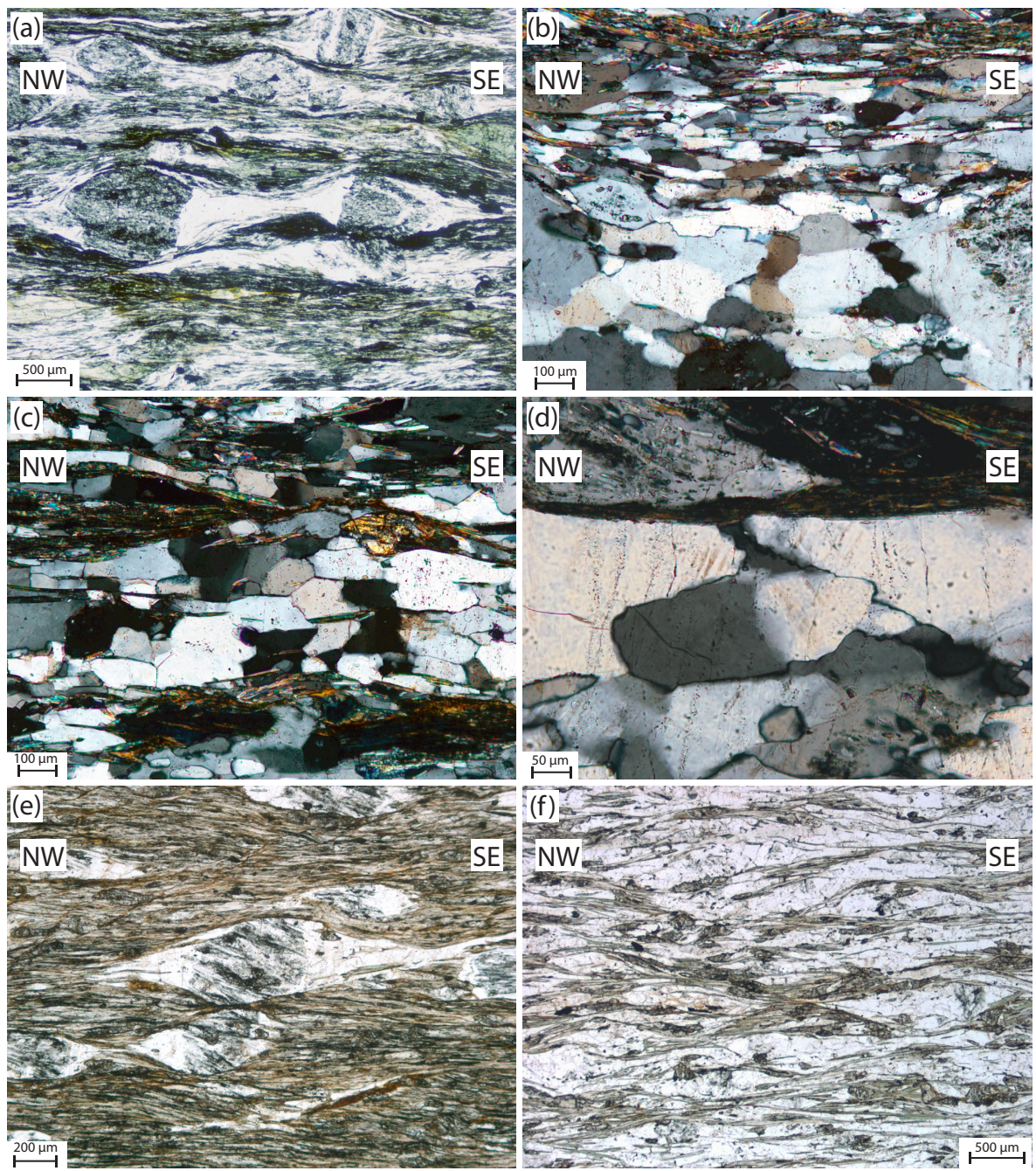

Figure 5. S2 fabric in metagreywacke. Sample locations are shown in Fig. 2a and listed in Table S1. (a) Quartz filled between two pulled-apart ablite porphyroblasts in the center of the image. Sample PS107. (b) Quartz precipitated in the pressure shadows between albite porphyroblasts. Sample PS185. (c) $Q$ domain in Sample PS190. (d) Undulose extinction and bulging in quartz grains precipitated in pressure shadows in Sample PS185. (e) Shear bands and asymmetric albite porphyroblast tails show a top-to-NW sense of shear. Sample PS185. (f) Conjugate shear bands outlined by white mica and chlorite in Sample PS139.

\subsection{Sense of shear during the deformation history}

Here we summarize information on the sense of shear in the Pelona Schist.

- It is not possible to determine the sense of shear during D1, as its original orientation was strongly modified during later deformation.

- The sense of shear during D2 varies depending on the structural level. For rocks structurally deeper than Iron Fork, though exceptions exist, the shear bands in metagreywacke and metachert show a top-to-NW sense of shear (Figs. 5e and 6e). The metachert sample PS186 (Fig. 6a) does not show an asymmetric geometry in its quartz $c$ axis pole figure (Fig. 6c) and therefore its sense of shear cannot be determined. For rocks structurally shallower than Iron Fork (south of Iron Fork), quartz pole figures of metachert samples show a topto-SE sense of shear. There is evidence of both senses of shear in the Iron Fork area. Metachert samples from the Iron Fork and structurally above all exhibit a topto-SE sense of shear, whereas boudinaged quartz veins in greenschist that is a few tens of meters structurally higher than Iron Fork exhibit an apparent top-to-NW sense of shear (Fig. 3b). There are indications that structures showing top-to-NW sense of shear were formed prior to the top-to-SE ones.

- The quartz recrystallized grain shape fabric developed during D3 implies a top-to-SE sense of shear. 

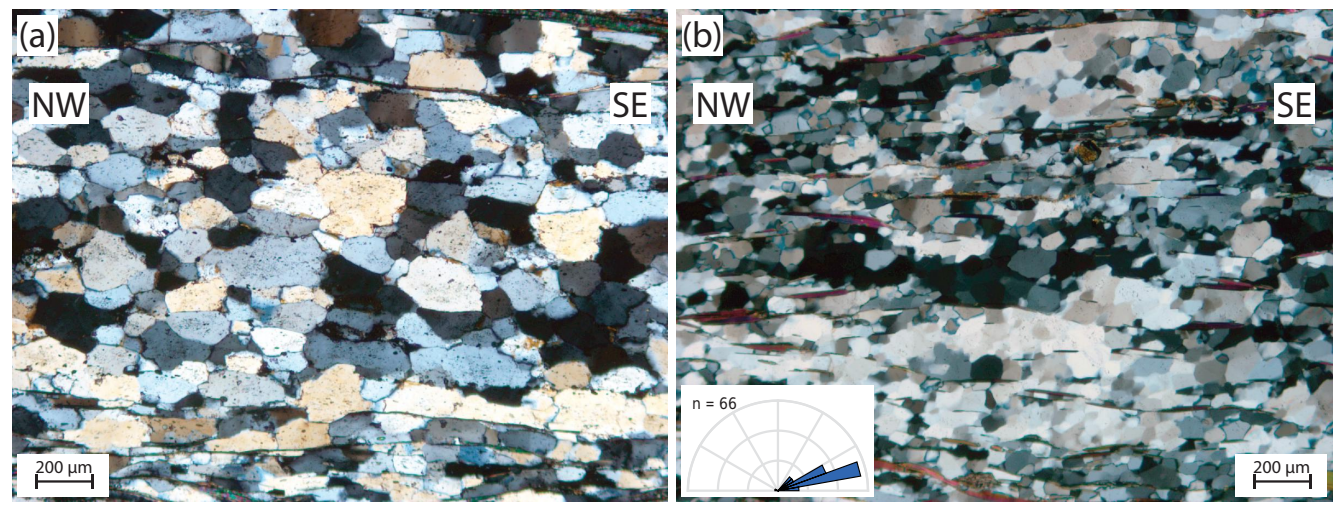

(c)
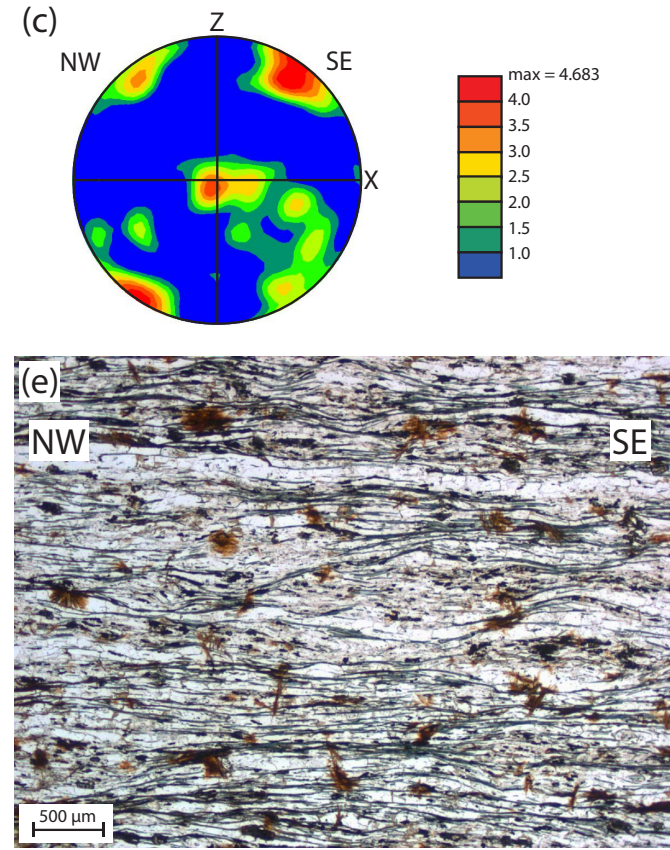

(d)
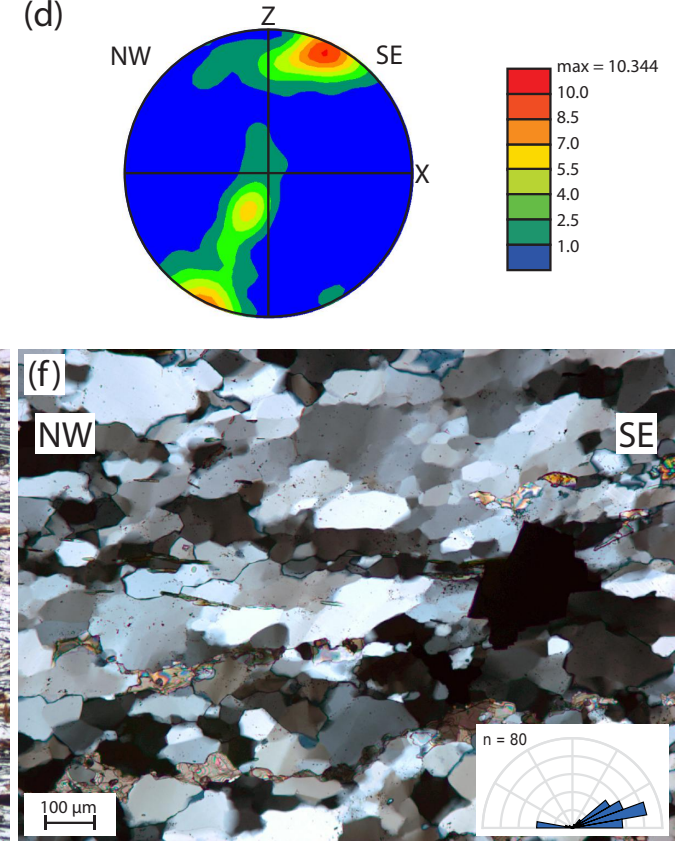

Figure 6. (a) Metachert from Prairie Fork (Sample PS186) and (c) its quartz CPO. The sense of shear cannot be inferred from panel (a) due to the lack of indicators. The quartz $c$ axis pole figure in panel (d) shows a symmetrical skeleton, but there are variations in density suggestive of top-to-SE sense of shear. (b) Metachert from Iron Fork (Sample PS103) and (d) its quartz CPO. The diagram in panel (b) illustrates the shape orientation of recrystallized quartz grains; quartz grains pinned by other minerals were not counted. Both quartz recrystallized grain fabric in panel (b) and quartz $c$ axis pole figure in panel (d) show a top-to-SE sense of shear. Note the grain size difference between panels (a) and (b). (e) Metachert with greenish needle-shaped amphibole and brown stilpnomelane. Sample PS131 from Fish Fork. Shear bands defined by amphiboles exhibit a top-to-NW sense of shear. (f) Metachert sample (PS100) from Iron Fork. The diagram in panel (f) illustrates the shape orientation of recrystallized quartz grains; quartz grains pinned by other minerals were not counted. The quartz recrystallized grain shape fabric and tilted prismatic subgrain walls indicate that the sense of shear was top-to-SE. Sample locations are available in Fig. 2a and Table S1.

\section{$5 \quad P-T-t$ path of Pelona Schist}

\subsection{Peak metamorphic temperature}

Raman spectroscopy on carbonaceous material (RSCM) and the opening angle of the quartz $c$ axis fabric thermometer were used to quantify the peak metamorphic temperature and/or to detect any possible inverted thermal gradient. A series of carbon-rich metagreywacke samples from a $4 \mathrm{~km}$ thick transect of Pelona Schist yield an average peak tem- perature of $519 \pm 20^{\circ} \mathrm{C}$ (see Table S1 in the Supplement for sample locations and Table S2 for detailed analysis results). All but a couple of the measurements lie within uncertainty of $\sim 512{ }^{\circ} \mathrm{C}$, and there is no obvious systematic trend of peak temperature across the East Fork cross section (Fig. 9). The peak temperatures of one metagreywacke and two metachert samples given by the quartz $c$ axis fabric opening-angle thermometer are 554 (PS185), 562 (PS186), and $527^{\circ} \mathrm{C}$ (PS187). Considering that this thermometer has a calibration uncer- 

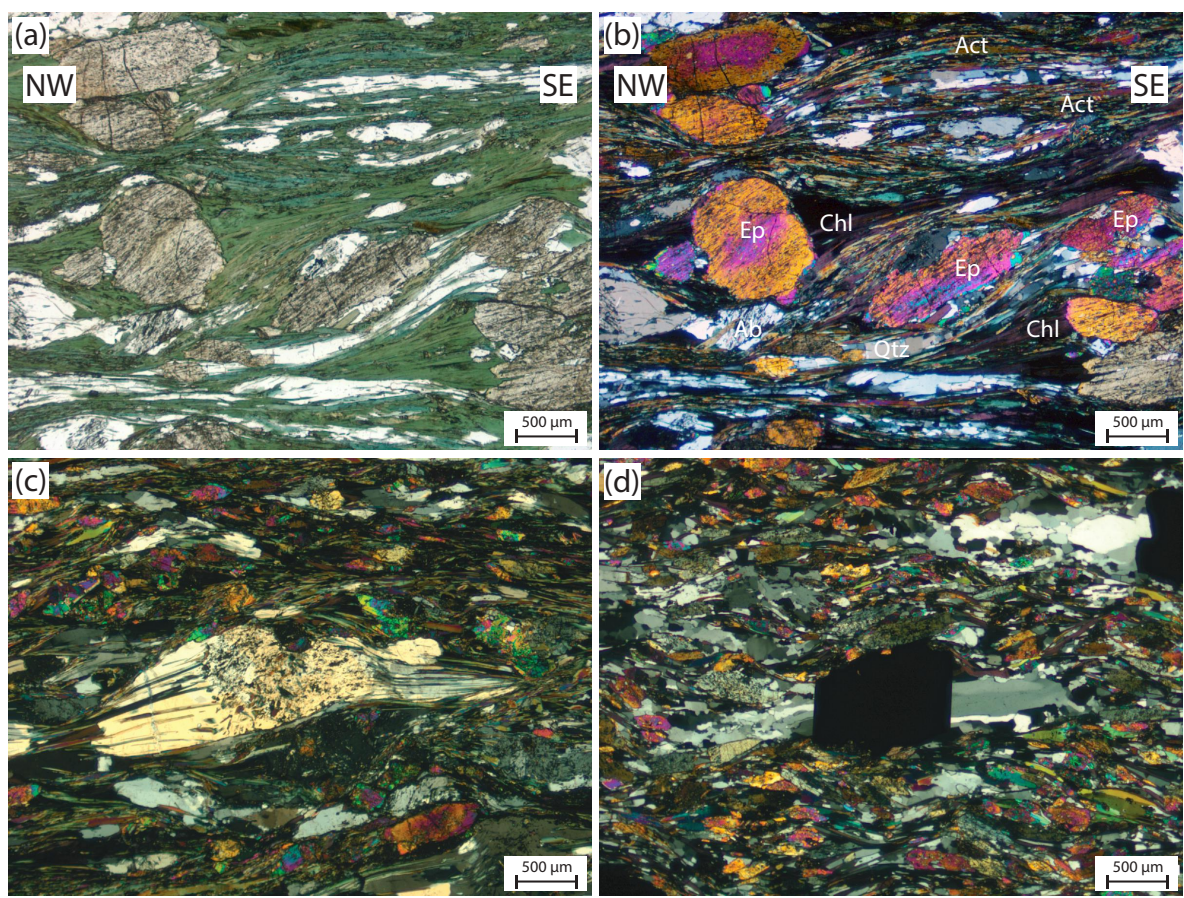

Figure 7. Mafic greenschist (sample PS193) showing S2 fabric under (a) plane light and (b) crossed polarized light. Ab: albite; Act: actinolite; Chl: chlorite; Ep: epidote; Qtz: quartz. (c) Crystallographically continuous overgrowths on an albite porphyroblast in mafic greenschist. Sample PS97. (d) Fibrous quartz strain shadow around a magnetite crystal in mafic greenschist. Sample PS101. Locations of samples can be found in Fig. 2a and Table S1.
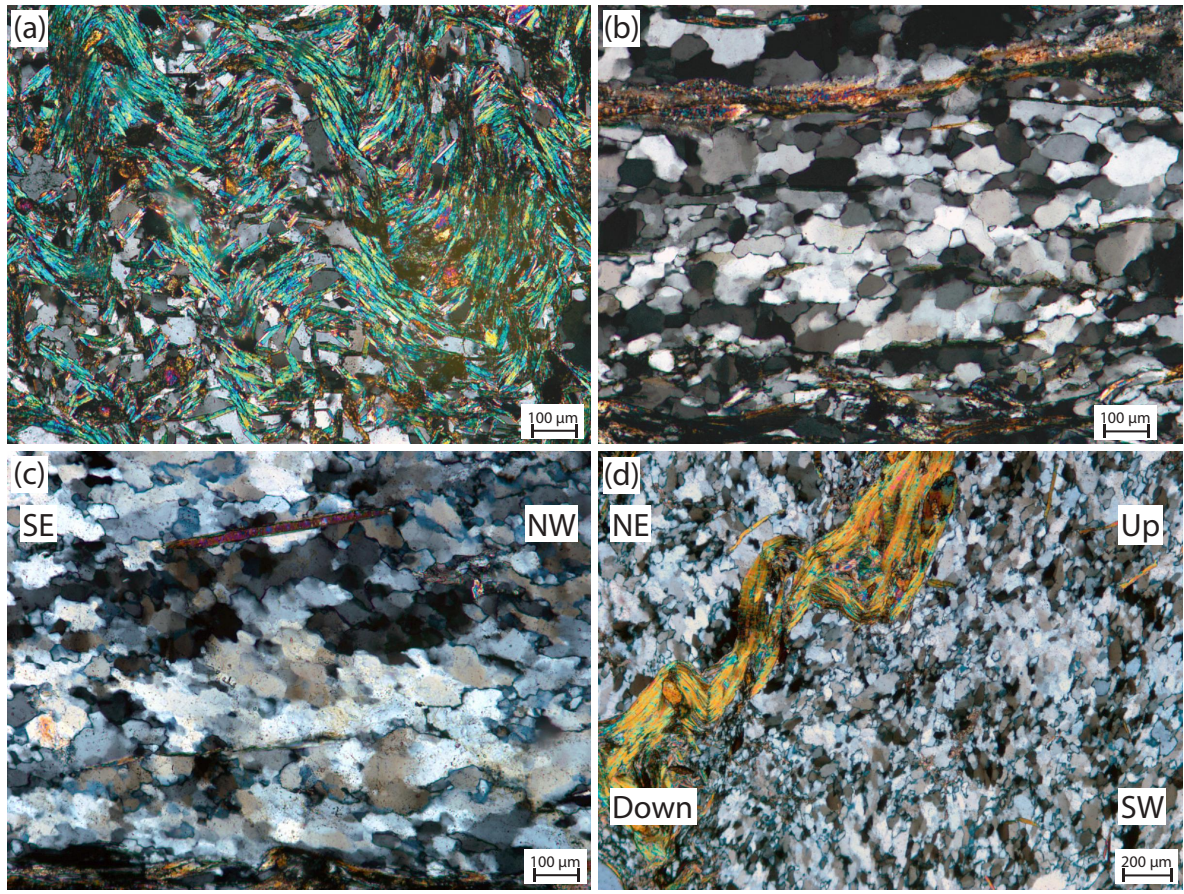

Figure 8. (a) D3 crenulations in Sample PS32 from the hinge of the Narrows synform. (b) Recrystallized quartz close to the hinge of the Narrows synform. Sample PS52. (c) Quartz in a mylonitized metagreywacke sample (PS36). (d) Lineation-perpendicular view of the mylonitized metagreywacke. S3 defined by the crenulated white mica is sub-vertical, and so is the quartz shape preferred orientation. Sample PS35. See Fig. 2a and Table $\mathrm{S} 1$ for sample locations. 


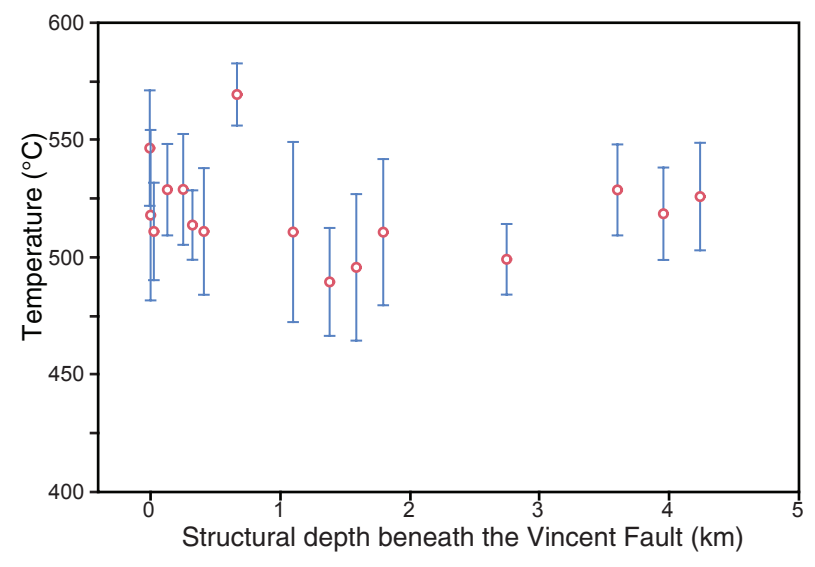

Figure 9. Peak temperature of Pelona Schist constrained by laser Raman spectroscopy. See Tables S1 and S2 for sample locations and detailed results.

tainty of $\pm 50^{\circ} \mathrm{C}$, the peak temperatures given by this thermometer are consistent with those from RSCM.

\subsection{Peak metamorphic pressure}

Within the isoclinal folds, white mica wrapping albite in metagreywacke exhibits straight grain shapes parallel to the axial plane (S2) and is optically strain-free. The lack of large white mica grains in albite porphyroblasts indicates that the white mica outside albite presumably crystallized during S2 at or after peak conditions. The phengite barometer requires a mineral assemblage of phengite, K-feldspar, phlogopite and quartz, whereas it will give a minimum pressure if phengite only coexists with a $(\mathrm{Mg}$ $\mathrm{Fe}$ ) silicate (Massonne and Schreyer, 1987). Samples analyzed were all metagreywacke with a mineral assemblage of phengite + quartz + stilpnomelane/biotite and do not contain K-feldspar, so the results given by this barometer are minimum pressures. The average $\mathrm{Si}$ content is $3.39 \pm 0.03$ atoms per formula unit (a.p.f.u.) of white mica, i.e., $\mathrm{K}\left(\mathrm{Mg}, \mathrm{Fe}^{2+}\right)_{x} \mathrm{Al}_{2-x}\left[\mathrm{Si}_{3+x} \mathrm{Al}_{1-x} \mathrm{O}_{10}\right](\mathrm{OH})_{2}$, where $x$ is the number of $\mathrm{Mg}$ and $\mathrm{Fe}^{2+}$ atoms in the octahedral site (see Tables S1 and S3 for sample locations and analysis results). These results are consistent with the compositions of old white mica grains reported by Jacobson (1983a, 1984). Combined with the peak temperature, the peak pressure is $10.5 \pm 0.4 \mathrm{kbar}$. The result is similar to $10 \pm 1 \mathrm{kbar}$, the peak pressure of the Pelona Schist in the Sierra Pelona (Graham and Powell, 1984). The peak pressure corresponds to a depth of approximately $39 \mathrm{~km}$ with an assumed upper plate density of $2750 \pm 50 \mathrm{~kg} \mathrm{~m}^{-3}$.

\subsection{P-T conditions of mylonitization of Pelona Schist}

In mylonitized metagreywacke, coarse-grained white mica grains defining S3 are curved and show undulose extinction, whilst fine-grained white micas are usually free of lat- tice distortion. Some grains show compositional zonation in backscattered electron images. Electron probe results indicate that the cores of the zoned white mica have Si content $(\sim 3.35$ a.p.f.u.) similar to that of $\mathrm{S} 2$ white mica, and the rims of the zoned white mica have Si content similar to that of fine-grained white mica ( 2.25 a.p.f.u.; see Table $S 1$ for sample locations and Table S3 for analysis results). Quartz in one metagreywacke sample collected close to the Vincent Fault, which has a mylonitic microstructure as described previously, reveals a titanium concentration of $1.55 \pm 0.17 \mathrm{ppm}$ (see Table S1 for sample location and Table S4 for analysis results). Combination of phengite barometry and TitaniQ thermobarometry yields an average $P$ of $5.8 \pm 0.8$ kbar and $T$ of $390 \pm 13^{\circ} \mathrm{C}$, which can be attributed to this stage in the structural development of the schist.

\subsection{Timing of exhumation of Pelona Schist}

Several geochronological studies of Pelona Schist have been reported. The youngest ${ }^{206} \mathrm{~Pb} /{ }^{238} \mathrm{U}$ age of the detrital zircon from the Pelona Schist is $68 \mathrm{Ma}$ (Grove et al., 2003), marking the earliest possible time for the subduction of the protolith of the Pelona Schist. Three amphibole ${ }^{40} \mathrm{Ar} /{ }^{39} \mathrm{Ar}$ isochron ages from the greenschist in the East Fork area reported are $58.9 \pm 2.5,60.3 \pm 2.6$ and 73.4 $\pm 3.0 \mathrm{Ma}$ (Jacobson, 1990). Jacobson (1990) noted that the sample giving $73.4 \pm 3.0 \mathrm{Ma}$ age had an older isochron age than the plateau age, indicating an unusual case that the initial ${ }^{40} \mathrm{Ar} /{ }^{39} \mathrm{Ar}$ is less radiogenic than atmospheric argon, and this age should be treated with caution. Given that the youngest detrital zircon ${ }^{206} \mathrm{~Pb} /{ }^{238} \mathrm{U}$ age suggests that underthrusting of the Pelona Schist had not started until $68 \mathrm{Ma}$, the $73.4 \mathrm{Ma}$ amphibole ${ }^{40} \mathrm{Ar} /{ }^{39} \mathrm{Ar}$ age is unlikely to be reliable. The other two samples giving ages of $58.9 \pm 2.5$ and $60.3 \pm 2.6 \mathrm{Ma}$ do not have well-developed plateaus and Jacobson (1990) concluded that this could be due to excess radiogenic argon. However, the consistency of the amphibole and white mica ${ }^{40} \mathrm{Ar} /{ }^{39} \mathrm{Ar}$ ages suggests that they are reliable. The amphibole grains in the mafic schist grew at the beginning of $\mathrm{D} 2$ at $\sim 500^{\circ} \mathrm{C}$, which is at or below the closure temperature for the Ar system in $\mathrm{Ca}$ amphibole, and they were not affected by D3, so we interpret the amphibole ${ }^{40} \mathrm{Ar} /{ }^{39} \mathrm{Ar}$ ages as crystallization ages.

Jacobson (1990) reported white mica isochron ages of three metagreywacke samples of $60.8 \pm 0.6,58.1 \pm 0.8$ and $55.9 \pm 0.2 \mathrm{Ma}$, which decrease with structural depth. White micas of two Pelona Schist samples (SG69 from right beneath the Vincent Fault and SG532A from Prairie Fork, the structurally deepest level) from the East Fork area were analyzed by Grove et al. (2003). No excess ${ }^{40} \mathrm{Ar}$ was noticed except for the initial step of Sample SG532A. The ${ }^{40} \mathrm{Ar} /{ }^{39} \mathrm{Ar}$ total gas ages for SG69 and SG532A are 57.8 \pm 0.1 and $34.2 \pm 0.2 \mathrm{Ma}$, respectively. These results fit a trend that the ages decreases with increasing structural depth. Grove et al. (2003) suggest that the closure temperature for white mica in the Pelona Schist is $\sim 400^{\circ} \mathrm{C}$, which is the same as the 
temperature during D3 within uncertainty. We therefore interpret the age of SG69, which was affected by recrystallization during D3 mylonitization, as a crystallization age, and the age of SG532A, which contains D2 micas unaffected by D3, as a cooling age.

To better constrain the time when the Pelona Schist entered the brittle regime, we performed zircon fission track analysis on six metagreywacke samples from East Fork in this study. The zircon fission track age is as old as $\sim 46.9$ Ma immediately beneath the Vincent Fault, and becomes progressively younger toward the north except one outlier $(\sim 13.5 \mathrm{Ma})$, which may have been affected by nearly Miocene dikes (see Fig. 2b for sample locations in the cross section, Table S1 for detailed sample locations and Table S5 for analysis results). The sample from Prairie Fork has the youngest age of $\sim 23.5 \mathrm{Ma}$, which is consistent with the white mica ${ }^{40} \mathrm{Ar} /{ }^{39} \mathrm{Ar}$ age of $34.2 \pm 0.2 \mathrm{Ma}$ (Grove et al., 2003) from the same area. The results above imply that the top section of the Pelona Schist cooled through the zircon fission track closure temperature of $\sim 237^{\circ} \mathrm{C}$ around $\sim 46.9 \mathrm{Ma}$ (see Appendix A for the calculation of the closure temperature), and that the structurally deeper section of the schist experienced slow cooling over the next 20 million years.

\subsection{Implications of the pressure, temperature and time estimates}

\subsubsection{Deformation history}

We make the case here that the main foliation (S2) of the Pelona Schist in the San Gabriel Mountains preserves mineral assemblages and microstructures of retrograde metamorphism based on the following observations: (1) biotite rarely appears in the Pelona Schist in the San Gabriel Mountains, whereas biotite is more common in the Pelona Schist in Sierra Pelona (Graham and England, 1976; Graham and Powell, 1984); (2) garnet occurs exclusively as inclusions in albite porphyroblasts, where it was protected from retrogression; and (3) the compositional zonation of white mica indicates decompression and hence exhumation during its formation. A plausible explanation for these observations is that the Pelona Schist in the San Gabriel Mountains experienced retrograde metamorphism during which biotite and garnet were broken down to chlorite and white mica.

If $\mathrm{S} 2$ was formed during exhumation, it is likely that $\mathrm{S} 1$ formed during subduction, while $\mathrm{S} 3$ is related to later reactivation and mylonitization. As discussed in Sect. 4.2.3, S3 is characterized by crenulation of $\mathrm{S} 2$ and mylonitization, and therefore is inferred to postdate S2. Mylonitization in the Pelona Schist shows similar stress, pressure and temperature conditions as the mylonites immediately above the Vincent Fault in the upper plate (Xia and Platt, 2017), and therefore may have occurred at the same time.

It should be noted that the subduction zone and the Vincent Fault originally dipped $\mathrm{E}$ and have been rotated and tilted afterwards into their present orientations. Paleomagnetic study of Neogene volcanic rocks in the San Gabriel block bounded by the San Gabriel Fault and the San Andreas Fault yielded a net clockwise rotation of $37.1^{\circ} \pm 12.2^{\circ}$ since the early Miocene (Terres and Luyendyk, 1985). As a result, the subduction channel was rotated to a SE dip, and the top level of the subduction channel shows top-to-SE sense of shear. The Vincent Fault and the Pelona Schist now dip $\mathrm{SW}$ in the limb of a faulted NW-trending antiform that was produced during Neogene motion on the San Andreas and Punchbowl faults.

The D3 mylonitic fabric only occurs in the top $100 \mathrm{~m}$ beneath the Vincent Fault and shows a top-to-SE sense of shear, so D3 is likely to be related to the Vincent Fault, and the motion direction of the Vincent Fault was top to SE. After correcting for the early Miocene vertical-axis rotation (Terres and Luyendyk, 1985), the sense of shear was initially top-toE. We conclude that the Vincent Fault dipped E initially and its sense of shear was top to E. Therefore, the Vincent Fault had a normal sense of motion.

\subsection{2 $P-T-t$ path of Pelona Schist}

With the above data, we are able to establish the metamorphic and deformational history of the Pelona Schist. The youngest detrital zircon ${ }^{206} \mathrm{~Pb} /{ }^{238} \mathrm{U}$ age of $\sim 68 \mathrm{Ma}$ (Grove et al., 2003) places constraints on the youngest age of the source rock of the Pelona Schist and on the earliest time of the subduction initiation. The peak metamorphic conditions are $10.5 \pm 0.4 \mathrm{kbar}$ and $519 \pm 20^{\circ} \mathrm{C}$ as indicated by the phengite barometer and RSCM. The timing of peak metamorphism is not known precisely, but it should be no later than $\sim 60.3 \mathrm{Ma}$ as constrained by the amphibole ${ }^{40} \mathrm{Ar} /{ }^{39} \mathrm{Ar}$ age of the mafic greenschist in the Narrows area (Jacobson, 1990). After reaching these conditions, part of the Pelona Schist was underplated and exhumed, firstly by ductile flow during D2, and then by normal sense motion on the Vincent Fault, accompanied by formation of the Narrows synform and associated mylonite (D3). The $P-T$ conditions during mylonitization were $5.8 \pm 0.8 \mathrm{kbar}$ and $390 \pm 13^{\circ} \mathrm{C}$ given by the phengite barometer and the TitaniQ thermometer. Mylonitization of the top section of the schist started at $\sim 55 \mathrm{Ma}$ implied by the white mica ${ }^{40} \mathrm{Ar} /{ }^{39} \mathrm{Ar}$ ages (Grove et al., 2003; Jacobson, 1990) and ceased by $\sim 43 \mathrm{Ma}$ as constrained by the zircon fission track ages of the schist immediately beneath the Vincent Fault (Fig. 10).

\section{Exhumation mechanisms of the Pelona Schist}

The tectonic setting of the Pelona Schist suggests that it was formed in a subduction channel rather than an accretionary wedge; therefore, exhumation models based on the accretionary wedge setting (Brandon et al., 1998; Platt, 1986; Ring et al., 2007) cannot be applied to the Pelona Schist. The flat- 

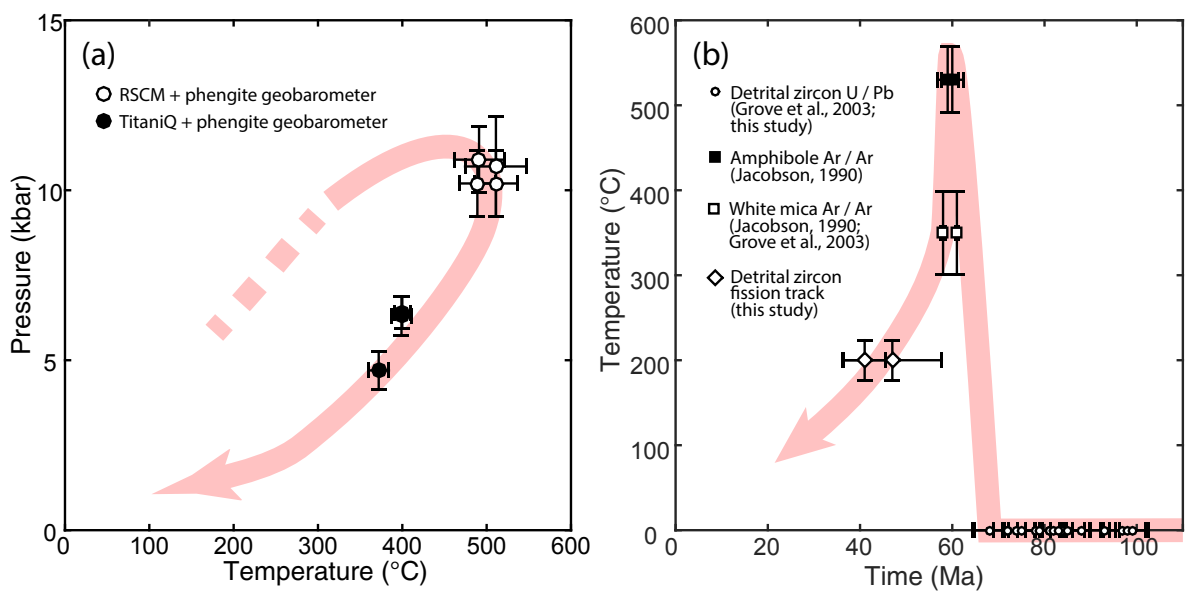

Figure 10. (a) $P-T-t$ path and (b) thermal history of Pelona Schist. RSCM: Raman spectroscopy on carbonaceous material; TitaniQ: titanium-in-quartz thermobarometer

slab Laramide subduction rules out the slab rollback as a possible exhumation mechanism (Brun and Faccenna, 2008).

Various models such as upper plate normal faulting (e.g., Jacobson et al., 2007), passive-roof thrusting and erosion (Yin, 2002), return flow (Oyarzabal et al., 1997), and channelized extrusion (Chapman et al., 2010) have been proposed to explain the exhumation of the Rand Schist, the schists of Portal Ridge and Sierra de Salinas, and the Orocopia schist. As for the Pelona Schist, it was still thought to preserve the original structural and metamorphic features related to subduction (Ehlig, 1981; Jacobson, 1983a, b, 1997; Jacobson et al., 1996) and no model has yet been proposed to account for its exhumation.

Normal faulting alone is unlikely to have brought the Pelona Schist from $\sim 39 \mathrm{~km}$ depth to the surface, as it cannot produce two opposing senses of shear in the lower plate. Erosion is not plausible for exhuming the Pelona Schist, either. The deep-water San Francisquito Formation in southern California was deposited from latest Cretaceous through middle Paleocene time (Kooser, 1982), indicating that the Sierra Pelona area was in a marine environment during the subduction and first stage exhumation of the Pelona Schist, and erosion was likely to be minimal. The channelized extrusion model (Chapman et al., 2010) can bring up the entire subduction assemblage as a whole. We think this is unlikely to be the case for the Pelona Schist, for two reasons. First, when $\mathrm{S} 2$ of the Pelona Schist, which is defined by the retrograde metamorphic mineral assemblages, was formed between 60 and $58 \mathrm{Ma}$, Pacific Ocean lithosphere was still subducting at a rate of $115 \mathrm{~mm} \mathrm{yr}^{-1}$ (Doubrovine and Tarduno, 2008) using a recent plate reconstruction (Müller et al., 2008), so that schist exhumation was coeval with ongoing subduction. Return flow allows the subducted material to be exhumed along roughly the same route as it descended, and makes the subduction channel a "two-way street" (Ernst, 1984). The second observation favoring return flow is that the whole of the exposed Pelona Schist in the East Fork shows evidence for large non-coaxial strains, which is not consistent with the channelized extrusion model.

In the classic return flow model, the velocity of rocks in a subduction channel results from a combination of Couette flow (laminar flow of a viscous fluid due to viscous drag) driven by the drag of the subducting plate and Poiseuille flow (laminar flow of a viscous fluid resulted from a pressure gradient) caused by the buoyancy of the low-density rocks in the subduction channel (Beaumont et al., 2009). In this model, the maximum subducting velocity occurs at the base of the channel, the maximum exhumation velocity occurs in the upper part of the channel, and the velocity at the roof of the channel is zero. When crossing the locus of the maximum exhumation velocity plane, the sense of shear changes because the velocity gradient changes its sign.

The change in sense of shear has been observed in D2. S2 shows a top-to-NW sense of shear at structurally deeper levels and a top-to-SE sense of shear at structurally shallower levels. In the return flow model the sense of shear changes from the bottom of the channel to the top, with the rocks in the return flow moving relatively northwestward. The locus of maximum exhumation velocity probably occurs around Iron Fork, where we observe conflicting senses of shear. In addition, the locus of the maximum exhumation velocity may have shifted through time, which would explain the conflicting shear senses in the quartz veins, metacherts, and greenschist in the Iron Fork area.

Return flow brought the Pelona Schist to a depth of $\sim 22 \mathrm{~km}$, marking the first stage of exhumation. The overprinting relationship between S2 and S3 implies that return flow ceased to act after D2. Return flow was immediately followed by the second-stage exhumation (Fig. 11). The mylonitized Pelona Schist right beneath the Vincent Fault indicates that the Vincent Fault exhumed the Pelona Schist to $8 \pm 4 \mathrm{~km}$ depth as constrained by the thermobarometric anal- 


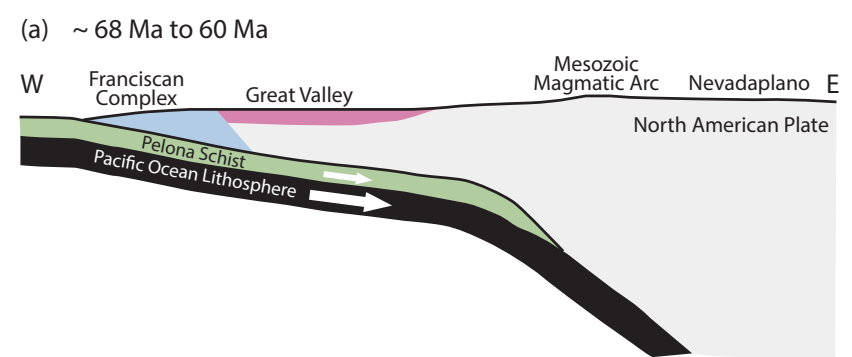

(b) $60 \mathrm{Ma}$ to $55 \mathrm{Ma}$

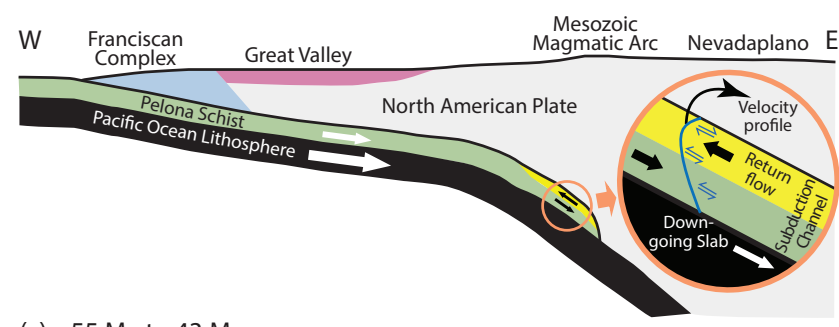

(c) $55 \mathrm{Ma}$ to $43 \mathrm{Ma}$

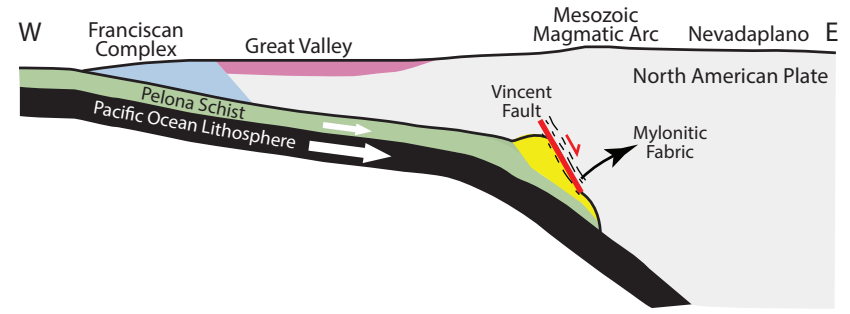

(d) Present (Mesozoic Magmatic Arc only; scale different from above) NW

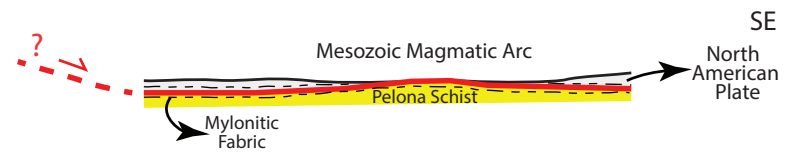

Figure 11. Tectonic model of the Pelona Schist. (a) The Pelona Schist was subducted no earlier than $68 \mathrm{Ma}$ and reached the peak condition by $60 \mathrm{Ma}$. (b) The Pelona Schist exhumed by return flow. Close-up view shows the velocity profile of the material in the subduction channel. (c) The Vincent Fault exhumed the Pelona Schist to a shallower structural level. (d) Present-day setting of the Vincent Fault and the Pelona Schist after rotation and tilting. The scale in panel (d) is larger than those in panels (a-c).

ysis of the upper plate (Xia and Platt, 2017). Similar extensional faulting of the upper plate has played an important role during the exhumation of other Laramide subduction-related schists from middle and lower crust to the upper crust (e.g., Chapman et al., 2010).

\section{Rheological interpretation}

Metagreywacke is the dominant rock type in the Pelona Schist, which makes up around $90 \%$ of the East Fork transect (Jacobson, 1983b). Albite does not develop any crystal-plastic deformation microstructures, while sheet silicates were mainly crenulated/kinked during S3, so quartz is likely to account for most of the strain in metagreywacke.
Metachert interlayers in metagreywacke do not show boudinage or buckle folds without the surrounding metagreywacke or greenschist being involved, implying that metachert and metagreywacke were coupled during deformation. This suggests that the values of strain rate estimated from one type of rock can be applied to another. Deformation mechanisms evolve through time and vary among the three types of rocks in the Pelona Schist.

\subsection{D1}

The absence of CPOs (Fig. 4c), presence of differentiated cleavage (Fig. 4a), and lack of evidence of crystalline plastic deformation indicate that pressure solution was the dominant deformation mechanism during S1. Paleopiezometry was not applicable due to the lack of dynamic recrystallization. All we can say about the stress conditions is that, by the end of the subduction (transition from D1 to D2), the shear stress was less than $10 \mathrm{MPa}$ (see Sect. 7.2.1). The peak temperature at this time was $519 \pm 20^{\circ} \mathrm{C}$ given by RSCM.

\section{$7.2 \quad \mathrm{D} 2$}

The broad distributive ductile deformation during D2 indicates that the Pelona Schist was below the down-dip limit of seismicity during $\mathrm{D} 2$, which is consistent with the absence of pseudotachylite.

\subsubsection{Quartz in metagreywacke}

In the metagreywacke from the lower limb of the Narrows synform, the strong differentiation of mica and other sheet silicate minerals into $P$ domains, concentration of quartz in $Q$ domains and pressure shadows, the precipitation of quartz in the pull-aparts of albite grains, and the existence of fluid inclusions in quartz grains indicate that pressure solution was the dominant deformation mechanism (Fig. 5a-e). The source of the quartz is likely to have been what are now the mica-rich $P$ domains, and the sinks include the pressure shadows around the albite porphyroblasts. Dynamic recrystallization and undulose extinction in quartz imply that dislocation creep probably occurred immediately after if not contemporaneously with pressure solution, and also contributed to the D2 deformation (Fig. $5 \mathrm{~d}$ and f). The average recrystallized quartz grain size is $\sim 75 \mu \mathrm{m}$, indicating the shear stress during recrystallization was less than $10 \mathrm{MPa}$ (Table 1). It should be noted that the stress estimates here may only represent the maximum stress during pressure solution if quartz recrystallized after pressure solution during exhumation. The peak temperature is constrained to $519 \pm 20^{\circ} \mathrm{C}$, but retrogression during D2 suggests that temperature decreased during deformation. 


\subsubsection{Quartz in metachert}

In the lower limb of the Narrows synform, strong crystallographic preferred orientation of quartz in metachert indicates that dislocation creep was the dominant deformation mechanism in this rock type, though in some samples the related microstructures were strongly modified by subsequent annealing, as quartz shows equant grain shapes, straight grain boundaries and $120^{\circ}$ triple points (Fig. 6a). From the grain size of recrystallized quartz or quartz grains preserved in albite porphyroblasts varies between 47 and $82 \mu \mathrm{m}$, and the inferred shear stresses range between $8.3+2.7 /-1.5$ and $12.9+3.9 /-2.3 \mathrm{MPa}$ (Table 1 ).

\subsection{D3}

Crenulation cleavage in the hinge of the Narrows synform indicates that microfolding of the S2 foliation accompanied by pressure solution was the dominant deformation mechanism there (Fig. 8a).

In the upper limb of the Narrows synform, quartz in the metagreywacke underwent dynamic recrystallization. Subgrain rotation was the dominant recrystallization mechanism but bulging occurred subsequently. This suggests that quartz was mainly deformed by climb-accommodated dislocation creep. We estimate the temperature of recrystallization at $390 \pm 13^{\circ} \mathrm{C}$. The average grain size of recrystallized quartz grains is $28 \pm 9 \mu \mathrm{m}$, indicating a shear stress of $\sim 20 \mathrm{MPa}$ (Table 1).

\section{Estimates of shear zone widths and strain rates}

The width of the subduction channel is estimated as $10 \pm 5 \mathrm{~km}$ based on the thickness of the observed lowvelocity anisotropic layer in the middle to lower crust of the southern California (Lee et al., 2014; Li et al., 1992; Porter et al., 2011). We assume that the $4 \mathrm{~km}$ thick Pelona Schist in the eastern San Gabriel Mountains formed part of the zone of return flow during $\mathrm{D} 2$, and the remaining $6 \pm 5 \mathrm{~km}$ thickness of Pelona Schist formed the zone of subduction flow in the channel.

The subduction of the protolith of the Pelona Schist started no earlier than $68 \mathrm{Ma}$ (Grove et al., 2003) and it reached the maximum depth by $60 \mathrm{Ma}$ as discussed in Sect. 5, during which the estimated rate of convergence between Pacific Ocean lithosphere and North America was over $110 \mathrm{~mm} \mathrm{yr}^{-1}$ (Doubrovine and Tarduno, 2008). The source of non-volcanic tremor in subduction zones is near the downdip limit of megathrust earthquakes (Ide et al., 2007), and a down-dip limit of $25 \mathrm{~km}$ has been estimated for the presentday Cascadia margin (Chapman and Melbourne, 2009). The Pelona Schist was at depths of $25-39 \mathrm{~km}$ and at temperatures of $\sim 500^{\circ} \mathrm{C}$, during at least the earlier stages of D2, so there may have been very limited discrete slip along the megathrust at this time. Assuming that subduction was accommo- dated within the $6 \pm 5 \mathrm{~km}$ thick down-going section of the subduction channel, the plate motion rate above corresponds to a strain rate between $3.2 \times 10^{-13}$ and $3.5 \times 10^{-12} \mathrm{~s}^{-1}$ in this section of the subduction channel between 25 and $39 \mathrm{~km}$ depth. The range of this estimated strain rate was caused by the uncertainty of the subduction channel width.

During the first stage of exhumation, the Pelona Schist was decompressed from $10.5 \pm 0.4$ to $5.8 \pm 0.8 \mathrm{kbar}$, which is approximately equivalent to a vertical exhumation of $17.4 \mathrm{~km}$ from 60 to $58 \mathrm{Ma}$. With a channel geometry as discussed in Appendix B, the displacement rate in the zone of return flow was 17 to $70 \mathrm{~mm} \mathrm{yr}^{-1}$ and hence the maximum strain rate was $1.4 \times 10^{-13}$ to $5.5 \times 10^{-13} \mathrm{~s}^{-1}$. The wide ranges of the displacement rate and the strain rate are primarily due to the overlapping amphibole and white mica ${ }^{40} \mathrm{Ar} /{ }^{39} \mathrm{Ar}$ ages, which constrain the time period for the first stage of exhumation to between 1 and $4 \mathrm{Myr}$.

The width of the mylonitized Pelona Schist is $\sim 100 \mathrm{~m}$, and the lower $200 \mathrm{~m}$ of the mylonite zone in the hanging wall of the Vincent Fault shows similar quartz microstructures and metamorphic conditions as those in the Pelona Schist. Thermobarometric data (Xia and Platt, 2017) from the hanging-wall mylonites show that the mylonites were decompressed to $2.0 \pm 1.0 \mathrm{kbar}$ by the end of D3. As shown in Appendix A, the mylonites crossed the $300^{\circ} \mathrm{C}$ isotherm at around $51.1 \mathrm{Ma}$, when ductile deformation ceased. Assuming the shear zone originally dipped $\sim 30^{\circ}$, the estimated average strain rate during mylonitization was $4.5 \pm 1.2 \times 10^{-13} \mathrm{~s}^{-1}$. The uncertainty of the strain rate results from the uncertainty of the pressure at the end of D3. This is slightly higher than the range of $1.3 \times 10^{-14}$ to $1.1 \times 10^{-13} \mathrm{~s}^{-1}$ given by the quartz dislocation creep flow law (Hirth et al., 2001) for the estimated shear stress of $20.1+7.3 /-4.0 \mathrm{MPa}$ (differential stress of $34.8+12.7 /-7.0 \mathrm{MPa}$ ), temperature of $390^{\circ} \mathrm{C}$, and the maximum water fugacity at $390^{\circ} \mathrm{C}$ and $5.8 \mathrm{kbar}$.

\section{Discussion}

There are a number of issues arising from the data of this study, such as the inverted thermal gradient in the Pelona Schist, the driving forces of exhuming the Pelona Schist in return flow, the quartz pressure-solution flow law, and the change in quartz deformation mechanisms.

\subsection{Inverted thermal gradient of Pelona Schist}

The Pelona Schist in the Sierra Pelona is one of the classic examples of an inverted metamorphic gradient (e.g., Graham and England, 1976). In the Sierra Pelona the Pelona schist was metamorphosed up to amphibolite facies and shows an upward transition from high-pressure greenschist facies to amphibolite facies. The temperature ranges from $\sim 480$ to $620-650{ }^{\circ} \mathrm{C}$ upward in a $\sim 700 \mathrm{~m}$ thick transect, corresponding to an inverted thermal gradient of 170 to 
$250{ }^{\circ} \mathrm{C} \mathrm{km}^{-1}$ (Graham and Powell, 1984). In contrast, the Pelona Schist in the East Fork was metamorphosed to highpressure greenschist facies and its peak metamorphic temperature is lower than that in the Sierra Pelona by about $100^{\circ} \mathrm{C}$. Jacobson (1995) noted the systematic composition variations in the amphibole of the greenschist and argued that there was inverted metamorphic zonation. However, no inverted thermal gradient can be observed from our peak temperature estimates in the $4 \mathrm{~km}$ thick transect in the East Fork. It is possible that no inverted thermal gradient was developed in East Fork area, though it cannot be excluded that the high-temperature section of the Pelona Schist in the San Gabriel Mountains was cut off by the Vincent Fault.

\subsection{Topography- and density-driven return flow model of subduction channels}

To compare the stress and strain rate estimates of the return flow with the geodynamic model, we used the analytical formulation given by Beaumont et al. (2009). This onedimensional formulation assumes that the rocks in the channel have a linear viscous rheology (appropriate for pressuresolution creep). The stress and strain rate profiles across the subduction channel can be calculated for a given channel geometry, viscosity of material in the channel, and the pressure gradient in the subduction channel. Behr and Platt (2013) modified this formulation, so as to relate the viscosity to the maximum exhumation rate.

The buoyancy contrast between the subducting material and the overlying upper plate has been proposed as the driving force for return flow (e.g., England and Holland, 1979; Ernst et al., 1997). The density of the Pelona Schist, which consists of $90 \%$ metagreywacke, is $\sim 2700 \mathrm{~kg} \mathrm{~m}^{-3}$. The overriding plate, after the removal of its high-density batholithic root during the Laramide subduction, is mainly made up of felsic batholiths and felsic plutons with gabbronorite to gabbrodiorite intrusives at the bottom of the crustal column (Saleeby et al., 2003). The average density of the overriding plate is assumed as $2750 \pm 50 \mathrm{~kg} \mathrm{~m}^{-3}$. Thus, the density contrast between the schist and the upper plate could be $50 \pm 50 \mathrm{~kg} \mathrm{~m}^{-3}$ and might not be sufficient to drive return flow.

The topographic gradient between the trench and the arc could act as the major driving force for return flow, as described in Appendix C. The pressure gradient due to the topographic difference can be up to $969 \mathrm{~Pa} \mathrm{~m}^{-1}$, whereas that caused by the density contrast is only $105 \mathrm{~Pa} \mathrm{~m}^{-1}$ with a density of $2750 \mathrm{~kg} \mathrm{~m}^{-3}$ for the upper plate. If D2 lasted $2 \mathrm{Myr}$, the Poiseuille flow driven by the topographic gradient can be up to $74.5 \mathrm{~mm} \mathrm{yr}^{-1}$, whereas that driven by the density contrast is only $8 \mathrm{~mm} \mathrm{yr}^{-1}$ (Fig. 12).

We have modified the pressure gradient by adding the effect of topography to that generated by the density contrast, as shown in Appendices B and C. With a pressure gradient caused by both topography and density contrast, the one-

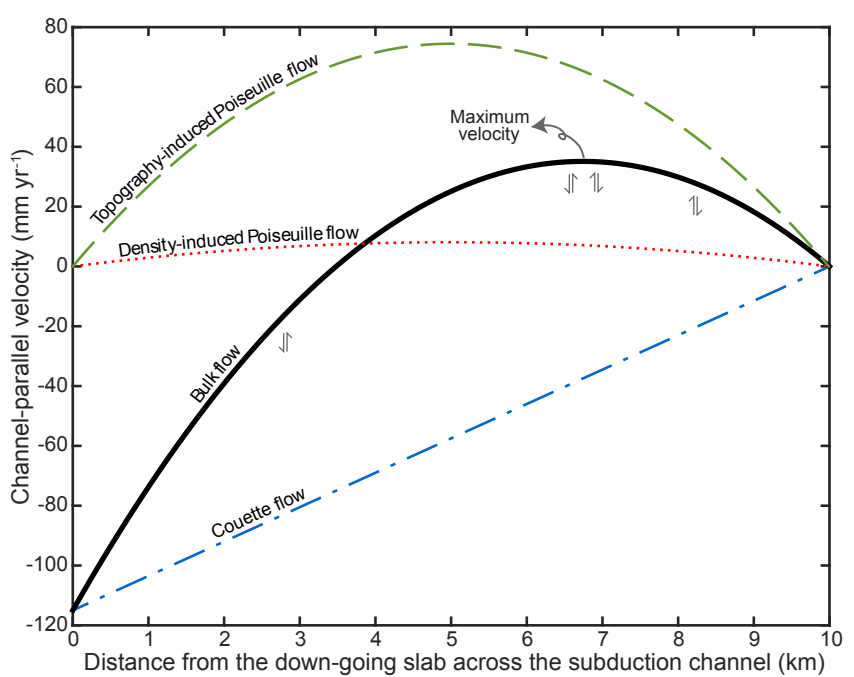

Figure 12. Velocity profile across the subduction channel filled by linear viscous material. Subduction velocity is negative and exhumation velocity is positive. Blue dash-point line: Couette flow caused by the drag of the subducting plate; red dotted curve: Poiseuille flow driven by the buoyancy of the material in the subduction channel; green dashed curve: topography induced Poiseuille flow; thick black solid curve: the bulk flow of rocks in the subduction channel. Note the sense of shear changes when crossing the line of maximum velocity. The duration of D2 was $2 \mathrm{Myr}$ for calculation. See Appendix D for details.

dimensional model given by Beaumont et al. (2009) yields a shear stress along the upper surface of the channel of $\sim 10 \mathrm{MPa}$, and a strain rate of $4.2 \times 10^{-13}$ to $1.2 \times 10^{-12} \mathrm{~s}^{-1}$ with the duration of D2 varying between 1 and 4 Myr. These results generally agree with our estimates for the first stage exhumation of the Pelona Schist.

\subsection{Implications for the pressure-solution flow law of quartz}

Pressure solution is a common deformation mechanism in low-grade metamorphic conditions, but it remains poorly understood and its flow law is loosely constrained. The three primary models for pressure solution are the thin-film model (Rutter and Elliott, 1976; Weyl, 1959), the island channel model (Cox and Paterson, 1991; Raj, 1982), and the stresscorrosion micro-cracking model (den Brok, 1998; Gratz, 1991). The thin-film model assumes that the transport of dissolved material occurs by diffusion in a fluid film a few nanometers thick along grain boundaries, and that the rate of pressure solution is governed by the grain boundary diffusivity (Rutter and Elliott, 1976; Weyl, 1959). In the island channel model the fluid fills channels that surround islands where the grain boundaries are in contact. The rate of deformation in this model is controlled by the diffusivity of solute in the fluid-filled channel (Raj, 1982). A more sophisticated model, the stress-corrosion micro-cracking model, assumes 

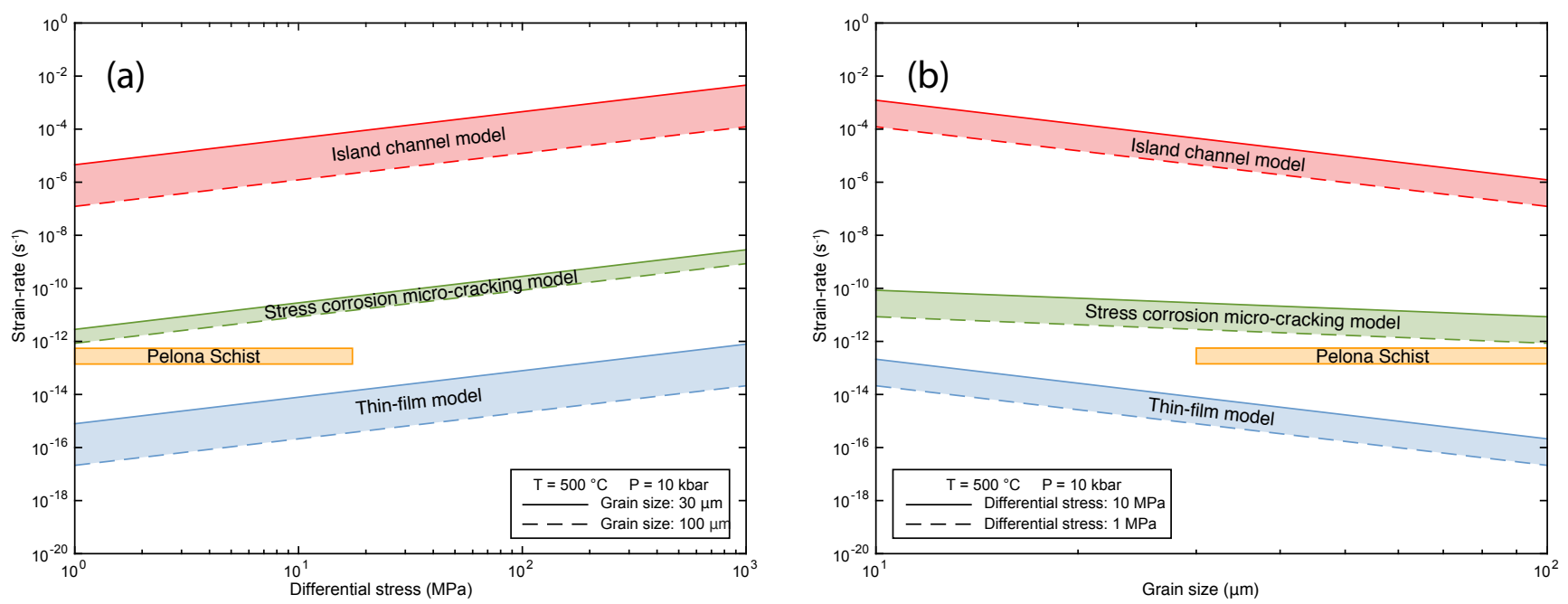

Figure 13. (a) Stress-strain-rate curve and (b) grain size-strain-rate curve of three pressure-solution flow laws. The orange zones are the estimated strain rate of the Pelona Schist.

that continuously produced micro-cracks along grain boundaries due to stress corrosion can cause a rough grain-surface topography, and material is transported through the plumbing network consisting of grain boundary film, capillary network of the micro-cracks along grain boundaries and wide pores between grains (Gratz, 1991). In this model the rate of deformation is inversely proportional to the square of the island diameter instead of the square of the average grain diameter (also see Appendix E).

The above three models can be tested by our estimated values of the rheological parameters from the Pelona Schist. Deformation of metagreywacke during D2 was dominated by pressure solution. Our strain-rate estimate for this stage is $1.4 \times 10^{-13}$ to $5.5 \times 10^{-13} \mathrm{~s}^{-1}$ and the shear stress was less than $\sim 10 \mathrm{MPa}$. The dynamically recrystallized grain size of quartz in metagreywacke varies between 30 and $100 \mu \mathrm{m}$. Comparison between the above estimates and the stressstrain rate curves predicted by those three models for pressure solution shows that strain-rate estimates from the Pelona Schist lie between the predictions of the stress-corrosion micro-cracking model and the thin-film model, whereas that forecast by the island channel model is many orders of magnitude faster (Fig. 13).

Our strain-rate estimates are likely to be somewhat higher than those predicted by theoretical models for pressure solution in pure quartz, as shown in Fig. 14a. This may be because of the abundance of white mica in Pelona Schist. It has long been observed that phyllosilicates can increase rates of dissolution (Bukovská et al., 2015; Heald, 1956; Rutter and Elliott, 1976; Wassmann and Stöckhert, 2013; Weyl, 1959), and differences in electrochemical potential between unlike minerals, e.g., quartz and mica, have been proposed as the driving force of dissolution (Greene et al., 2009; Kristiansen et al., 2011; Meyer et al., 2006). Probably due to the rela- tively high content of white mica, metagreywacke in Pelona Schist yielded a higher strain rate than the prediction of the thin-film model. This also explains the distinct deformation behavior of metachert from metagreywacke in Pelona Schist. The lack of mica in metachert resulted in too low a strainrate contribution from pressure solution, and therefore dislocation creep became the dominant deformation mechanism.

An additional factor is that dislocation creep is likely to have contributed to the bulk strain-rate estimates. Quartz shows undulose extinction and dynamic recrystallization in metagreywacke samples that also reveal clear evidence of pressure solution such as differentiated cleavage and precipitation of quartz in pressure shadows. Coexistence of those two types microstructures may indicate that the total deformation resulted from both pressure-solution and dislocation creep.

\subsection{Transition from pressure-solution to dislocation creep}

When the Pelona Schist entered the D3 regime, the dominant deformation mechanism of metagreywacke changed from pressure solution of quartz to dislocation creep of quartz (Fig. 14b). Two differences between D2 and D3 are shear stress and temperature. Shear stresses recorded by the Pelona Schist during D2 are less than those in D3, while the temperature was higher. When dynamic recrystallization is not dominant, so that the average grain size is not controlled by stress, the strain rate caused by quartz pressure solution is proportional to the first power of differential stress (den Brok, 1998), whereas the strain rate produced by quartz dislocation creep is proportional to the fourth power of the differential stress (Hirth et al., 2001). That is, quartz pressure solution is much less sensitive to stress compared to quartz dislocation creep. During S3, shear stresses increased to a few tens 

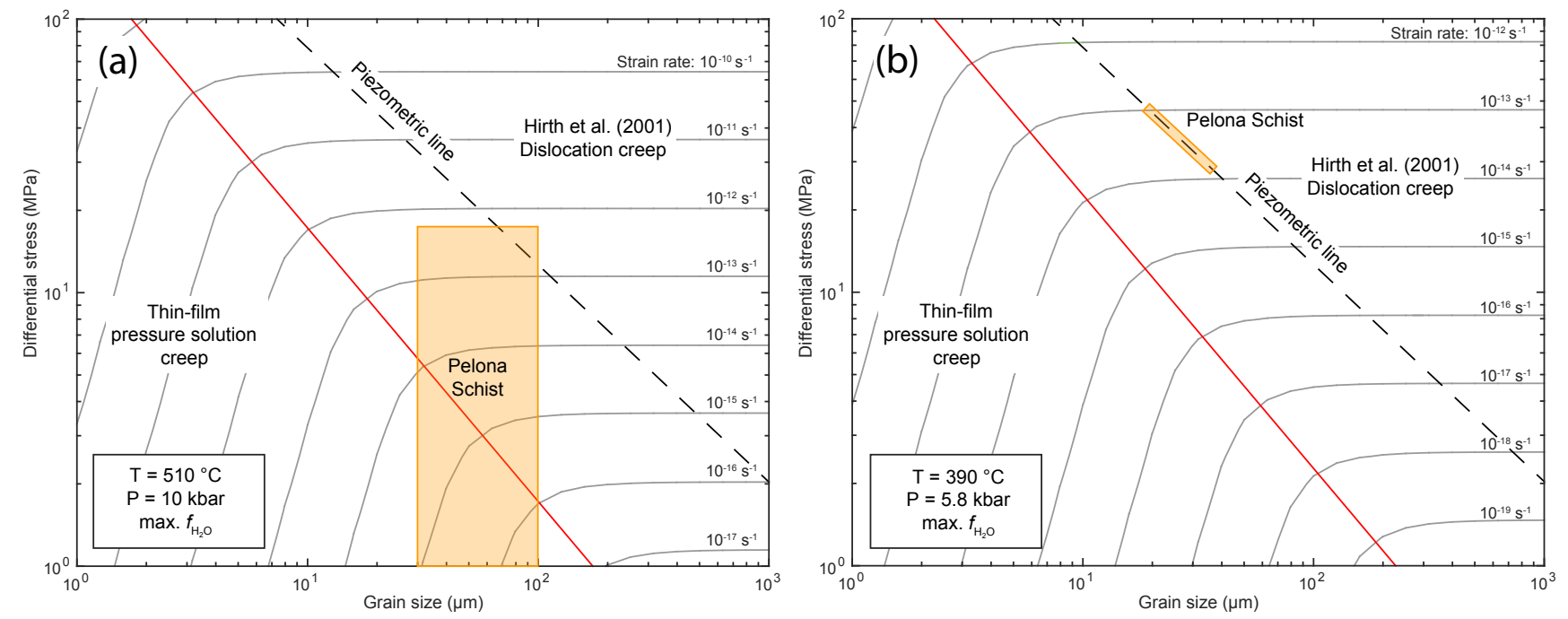

Figure 14. Deformation mechanism maps for (a) D2 and (b) D3. In both maps, the red line marks the boundary between the regime of quartz pressure solution and that of quartz dislocation creep, the black dashed line is calculated using the recrystallized quartz grain size piezometer (Stipp and Tullis, 2003), and the orange shaded area is the Pelona Schist in the grain size-stress space. See text for discussion.

of megapascals and dramatically expedited dislocation creep. Thus, crystal plastic deformation became the leading deformation mechanism during S3.

Increased stress also changed the scale of the shear zone. Grain size reduction due to dynamic recrystallization caused strain localization during S3. One clue is that the exposed width of the zone with $\mathrm{S} 3$ is $\sim 100 \mathrm{~m}$ while $\mathrm{S} 2$ penetrated the entire $4 \mathrm{~km}$ transect along the East Fork in the San Gabriel Mountains.

\section{Conclusions}

New microstructural observations, thermobarometric analysis and geochronologic data were used to constrain the deformation history and rheological properties of the Pelona Schist during Late Cretaceous-Paleocene Laramide subduction. The primary conclusions are as follows:

1. The Pelona Schist preserves a record of deformational and metamorphic processes from subduction to exhumation. The Pelona Schist was subducted no earlier than $68 \mathrm{Ma}$, and reached the peak $P-T$ condition of $10.5 \pm 0.4 \mathrm{kbar}$ and $519 \pm 20^{\circ} \mathrm{C}$ by $\sim 60 \mathrm{Ma}$, after which it underwent two stages of exhumation: first by return flow within the channel and then along the Vincent Fault. By $\sim 43 \mathrm{Ma}$ the Pelona Schist entered the brittle regime.

2. The dominant deformation mechanism of the Pelona Schist during subduction (D1) and the first stage of exhumation (D2) was pressure solution. The presence of mica expedited quartz dissolution and may have increased the strain rate relative to the predictions of the currently available quartz pressure-solution flow laws based on monomineralic samples.

3. During the second stage of exhumation (D3), the Pelona Schist was deformed dominantly by dislocation creep. Strain localization occurred due to grain size reduction caused by dynamic recrystallization.

4. Our estimate of shear stress at the end of during subduction and first-stage exhumation is less than $10 \mathrm{MPa}$, while that during the second-stage exhumation increased to $20.1+7.3 /-4.0 \mathrm{MPa}$.

5. The estimated magnitude of shear stress and strain rate in the subduction channel agrees well with the flowchannel model for linear viscous creep. Our estimated stresses and strain rates during the second stage of exhumation are close to those estimated from the quartz dislocation creep flow law of Hirth et al. (2001).

Data availability. Locations of samples and field images are listed in Table S1, RSCM results in Table S2, white mica compositions in Table S3, TitaniQ analysis results in Table S4, and detrital zircon fission track results in Table S5. 


\section{Appendix A: Closure temperature of zircon fission track analysis and cooling rate}

The relation between the closure temperature of zircon fission track and the cooling rate can be written as

$$
\dot{T}=\frac{-R T_{\mathrm{c}}^{2}}{E_{50 \%} B e^{\frac{E_{50 \%}}{R T_{\mathrm{c}}}}},
$$

where $\dot{T}$ is the cooling rate, $T_{\mathrm{c}}$ the closure temperature, $R$ the gas constant, $E_{50 \%}$ the activation energy for $50 \%$ annealing, and $B$ a constant (Dodson, 1979). For $\alpha$-damaged zircon, Brandon et al. (1998) estimated $49.77 \mathrm{kcal} \mathrm{mol}^{-1}$ for $E_{50 \%}$ and $3.160 \times 10^{-22}$ Myr for $B$ based on natural $\alpha$ damaged zircon from Zaun and Wagner (1985) and Tagami et al. (1990).

The Pelona Schist immediately underneath the Vincent Fault cooled from the closure temperature of white mica $\left(400^{\circ} \mathrm{C}\right)$ to the closure temperature of zircon fission track $T_{\mathrm{c}}$ from $57.8 \mathrm{Ma}$ (Grove et al., 2003) to $46.9 \mathrm{Ma}$ (this study), and the average cooling rate can be written as

$\dot{T}=\frac{400-T_{\mathrm{c}}}{57.8-46.9}$

Equations (A1) and (A2) yields that the average cooling rate was $15.0^{\circ} \mathrm{C} \mathrm{Myr}^{-1}$ between 57.8 and $46.9 \mathrm{Ma}$, and the closure temperature for zircon fission track is $\sim 237^{\circ} \mathrm{C}$. By assuming a linear cooling history between 57.8 and $46.9 \mathrm{Ma}$, the Pelona Schist was cooled to $300^{\circ} \mathrm{C}$ at $51.1 \mathrm{Ma}$, i.e., the upper section of the Pelona Schist crossed the brittle-ductile transition zone at $51.1 \mathrm{Ma}$.

\section{Appendix B: Dip of the Laramide subduction channel}

We made the following assumptions about the dip of the subduction channel when the Pelona Schist was subducted:

1. The migration of the trench was negligible from Late Cretaceous, when the magmatic arc was active to the time when the Pelona Schist was subducted. This allows us to estimate the trench-arc distance.

2. Following the previous assumption, we assume that the Mesozoic trench-arc distance was approximately $250 \mathrm{~km}$ by comparison with the modern trench-arc gap of the northwestern United States and that the magmatic arc was about $100 \mathrm{~km}$ wide based on the present-day outcrop of the Sierra Nevada.

3. The depth of the trench was $\sim 4.5 \mathrm{~km}$ when the Pelona Schist was subducted. The Laramide shallow subduction was inferred to be result of the subduction of the Hess and Shatsky conjugate oceanic plateaux (Liu et al., 2010), while the former, which originated from the midocean ridge 110 to $100 \mathrm{Myr}$ before present (Vallier et al.,
1983) and intersected the North American plate about 70 Myr before present (Liu et al., 2010), is spatially and temporally related to the formation of the Pelona Schist. Therefore, the Pacific Ocean lithosphere adjacent to the western edge of North America was $\sim 40 \mathrm{Myr}$ old when the Hess Plateau was subducted. The bottom of a typical seafloor aged $40 \mathrm{Myr}$ is $\sim 4.5 \mathrm{~km}$ beneath the sea level as constrained by present-day observations and predicted by theoretical models (Johnson and Carlson, 1992; Turcotte and Schubert, 2002). The above depth is likely to increase by another $\sim 3 \mathrm{~km}$ along the trench due to buckling and flexure, resulting in a seafloor depth of $\sim 7.5 \mathrm{~km}$. The Hess Rise in the central North Pacific Ocean is currently about $3 \mathrm{~km}$ above the surrounding seafloor (Vallier et al., 1983), and if this holds true for the Hess conjugate, the overall trench depth would be $\sim 4.5 \mathrm{~km}$.

4. The depth of the subduction channel was $30 \mathrm{~km}$ underneath the western margin of the Mesozoic arc. This allows the Pelona Schist to remain beneath the Mesozoic magmatic arc after the first-stage exhumation, which is constrained by the fact that the Pelona Schist and other Laramide subduction-related schists crop out within the Mesozoic arc at present day. This assumption gives a subduction channel dip of $\sim 3.3^{\circ}$ between the trench and the arc.

5. The depth of the subduction channel was more than $45 \mathrm{~km}$ at the east margin of the Mesozoic arc. This fits the hypothesized $\sim 45-60 \mathrm{~km}$ thick crust of the Nevadaplano, which lasted well into Paleogene time (Ernst, 2009; Wernicke et al., 1996) and requires a minimum dip of $12.4^{\circ}$ for the subduction channel underneath the arc.

\section{Appendix C: Topography-induced pressure gradient}

Assume a monotonically increasing topography at constant rate over a transect width of $l$ (Fig. C1). The amount of increased elevation over the interested width $l$ is $h$. The slope of this transect is $\omega$. Therefore, one has

$h=l \times \tan \omega$.

A subduction zone dipping against the topographic slope lies underneath the slope. The dip of the subduction zone is $\gamma$. The distance between a point at the bottom of the overriding plate and the left end of the subduction zone is $x$. The relationship among $l, x$ and $\gamma$ is

$l=x \times \cos \gamma$.

Combine Eqs. (C1) and (C2) and one has

$h=x \times \cos \gamma \times \tan \omega$. 


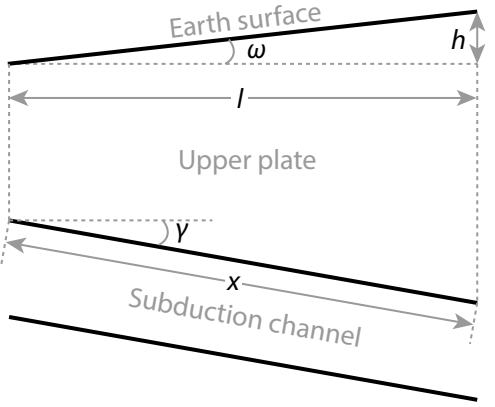

Figure C1. Geometry of topography and subduction channel.

The pressure $P$ caused by the topography of the upper plate is $\rho g h$, where $\rho$ is the density of the upper plate and $g$ is the gravitational acceleration. $P$ can be written as

$P=\rho g h=\rho g x \times \cos \gamma \times \tan \omega$.

$P$ increases with $x$ and works as the driving force of the exhumation of the rocks within the channel. The gradient of $P$ along the subduction channel is

$$
\frac{\partial P}{\partial x}=\rho g \times \cos \gamma \times \tan \omega=\frac{\rho g h}{l} \times \cos \gamma .
$$

The paleotopography of southern California in Late Cretaceous-Paleocene time could not be readily reconstructed because of the displacements associated with the San Andreas Fault and other Cenozoic faults. However, the paleogeomorphology of the southern end of the Great Valley and Sierra Nevada can shed light on the possible contemporaneous topography of southern California.

The Late Cretaceous depositional environment in the western foothills of the southern Sierra Nevada was fluvial-deltaic (Cherven, 1983). The elevation of the western foothills of the arc is unlikely to have been higher than $0.5 \mathrm{~km}$. To the east of the Mesozoic magmatic arc was the "Nevadaplano", a high and broad plain lasting from Late Cretaceous to Eocene (DeCelles, 2004). Its estimated average elevation was more than $3 \mathrm{~km}$ (DeCelles, 2004). The Sierra Nevada magmatic arc itself, which formed the west flank of the Nevadaplano (Henry, 2009), could have had an elevation up to $4 \mathrm{~km}$ at approximately $70 \mathrm{Ma}$ (House et al., 1998, 2001). Along the west slope of Sierra Nevada at that time, the elevation may have changed from $1 \mathrm{~km}$ in the west to more than $4 \mathrm{~km}$ in the east within a horizontal distance of $\sim 80 \mathrm{~km}$ (House et al., 2001).

The above geometric setting and an assumed rock density of $2700 \mathrm{~kg} \mathrm{~m}^{-3}$ yield a pressure gradient of $969 \mathrm{~Pa} \mathrm{~m}^{-1}$. In contrast, the density difference between the upper plate and the schist, which is assumed as $50 \mathrm{~kg} \mathrm{~m}^{-3}$, would generate a pressure gradient of $105 \mathrm{~Pa} \mathrm{~m}^{-1}$ with the same geometric setting.

\section{Appendix D: Calculations of channel flow stresses and strain rates}

In a parallel-sided subduction channel with a width of $L$, the velocity profile in a linear viscous fluid is

$v(z)=-\frac{\nabla P\left(z L-z^{2}\right)}{2 \eta}+V\left(1-\frac{z}{L}\right)$,

where $z$ is the distance to the base of the channel, $\nabla P$ the pressure gradient, $\eta$ the viscosity of material in the channel, and $V$ the subducting velocity (Beaumont et al., 2009; Behr and Platt, 2013).

The pressure gradient is caused by (1) the density contrast between the rocks in the subduction channel and those in the overriding plate and (2) the topography gradient as illustrated in Appendix B. The pressure gradient caused by density contrast is

$\nabla P_{\text {density }}=\left(\rho_{\text {up }}-\rho_{\text {sc }}\right) g \sin \gamma$,

where $\rho_{\text {up }}$ is the density of upper plate, $\rho_{\text {sc }}$ the density of rocks in the subduction channel, and $g$ the gravity acceleration (Beaumont et al., 2009; Behr and Platt, 2013). The sum of Eqs. (D2) and (C5) is the total pressure gradient:

$\nabla P=\left(\rho_{\text {up }}-\rho_{\text {sc }}\right) g \sin \gamma+\frac{\rho g h}{l} \times \cos \gamma$.

The viscosity $\eta$ is the lesser of the roots of Eq. (D4):

$\frac{4 V^{2}}{L^{2} \nabla P} \eta^{2}-4\left(V-2 v_{\mathrm{e}}\right) \eta+L^{2} \nabla P=0$,

where $v_{\mathrm{e}}$ is the maximum exhumation rate (Behr and Platt, 2013). $v_{\mathrm{e}}$ can be approximated as the ratio of $d_{2}$, displacement during $\mathrm{D} 2$ to $t$, the duration of $\mathrm{D} 2$.

The strain rate profile is

$v^{\prime}(z)=-\frac{\nabla P(L-2 z)}{2 \eta}-\frac{V}{L}$.

The stress profile (Behr and Platt, 2013) is

$\sigma(z)=v^{\prime}(z) \times \eta=-\frac{\nabla P(L-2 z)}{2}-\frac{V \eta}{L}$.

Parameters used for the stress and strain rate calculations in the subduction channel are listed in Table D1.

\section{Appendix E: Parameters used for flow law calculations}

As summarized by den Brok (1998) and Behr and Platt (2013), quartz pressure-solution flow laws can be written as

$\dot{\varepsilon}=\frac{A V_{\mathrm{m}} c D_{\mathrm{gb}} w \sigma \rho_{\mathrm{f}}}{R T d^{3} \rho_{\mathrm{s}}}$, 
Table D1. Parameters used for subduction channel calculations.

\begin{tabular}{|c|c|c|c|}
\hline Parameter & Description & Value & Reference and notes \\
\hline$L$ & Subduction channel width (km) & $10 \pm 5$ & Lee et al. (2014), Porter et al. (2011) \\
\hline$V$ & Subduction rate $\left(\mathrm{mm} \mathrm{yr}^{-1}\right)$ & 115 & Doubrovine and Tarduno (2008) \\
\hline$d_{2}$ & Displacement during D2 (km) & 69.8 & $\begin{array}{l}\text { Exhumed from } 39 \mathrm{~km} \text { deep to } 22 \mathrm{~km} \text { deep along a } \\
\text { subduction channel dipping } 12.4^{\circ} \text { as estimated in } \\
\text { Appendix B }\end{array}$ \\
\hline$t$ & Duration of D2 (Myr) & $1-4$ & Sect. 5.4 \\
\hline$\rho_{\mathrm{up}}-\rho_{\mathrm{sc}}$ & $\begin{array}{l}\text { Density contrast between the overriding } \\
\text { plate and the subduction channel }\left(\mathrm{kg} \mathrm{m}^{-3}\right)\end{array}$ & 50 & $\begin{array}{l}\text { For the calculations, } 2750 \mathrm{~kg} \mathrm{~m}^{-3} \text { is used for the } \\
\text { density of the upper plate and } 2700 \mathrm{~kg} \mathrm{~m}^{-3} \text { for the } \\
\text { density of the Pelona Schist. }\end{array}$ \\
\hline
\end{tabular}

Table E1. Parameters used for pressure-solution calculations.

\begin{tabular}{llll}
\hline Parameter & Description & Value & Reference and notes \\
\hline$A$ & Grain shape constant & 44 & den Brok (1998); 44 for spheric grains \\
$V_{\mathrm{m}}$ & Solid molar volume $\left(\mathrm{m}^{3} \mathrm{~mol}^{-1}\right)$ & $2.269 \times 10^{-5}$ & Berman (1988) \\
$c$ & Solubility of solid in fluid phase & $P$ and $T$ dependent & Fournier and Potter (1982) \\
$D_{\mathrm{gb}}$ & Grain boundary diffusivity & $T$ dependent & Farver and Yund (2000) \\
$D_{\text {fluid }}$ & Diffusivity in grain boundary fluid & $T$ dependent & Watson and Wark (1997) \\
$d_{\text {chan }}$ & Width of island channel $(\mu \mathrm{m})$ & 0.1 & den Brok (1998) \\
$d_{\text {isl }}$ & Island diameter $(\mu \mathrm{m})$ & 0.5 & Paterson (1995) \\
$w$ & Effective width of grain boundary $(\mu \mathrm{m})$ & 0.1 & Joesten (1983) \\
$\rho_{\mathrm{f}}$ & Density of fluid $\left(\mathrm{kg} \mathrm{m}^{-3}\right)$ & 923 & Behr and Platt (2013) \\
$\rho_{\mathrm{s}}$ & Density of solid $\left(\mathrm{kg} \mathrm{m}^{-3}\right)$ & 2650 & Behr and Platt (2013) \\
$R$ & Gas constant $\left.\left(\mathrm{J} \mathrm{K}^{-1} \mathrm{~mol}^{-1}\right)\right)$ & 8.314 & \\
$d$ & Grain size & Varies by sample & \\
\hline
\end{tabular}

$\dot{\varepsilon}=\frac{A V_{\mathrm{m}} c D_{\text {fluid }} d_{\text {chan }} \sigma \rho_{\mathrm{f}}}{R T d^{3} \rho_{\mathrm{s}}}$, and

$\dot{\varepsilon}=\frac{A V_{\mathrm{m}} c D_{\mathrm{gb}} w \sigma \rho_{\mathrm{f}}}{R T d_{\mathrm{isl}}^{2} d \rho_{\mathrm{s}}}$

for the thin-film model, the island channel model, and the micro-cracking model, respectively, where $\sigma$ is differential stress in $\mathrm{Pa}$ and $T$ the absolute temperature. The descriptions and values used for the parameters in Eqs. (E1) to (E3) are listed in Table E1.

Quartz dislocation creep flow law (Hirth et al., 2001) is

$\dot{\varepsilon}=A f_{\mathrm{H}_{2} \mathrm{O}} \sigma^{4} \exp \left(-\frac{Q}{R T}\right)$,

where $A$ is a material parameter, $f_{\mathrm{H}_{2} \mathrm{O}}$ water fugacity, $\sigma$ differential stress in megapascals, $Q$ the activation energy, $R$ the ideal gas constant, and $T$ the absolute temperature. As constrained by Hirth et al. (2001), $A$ equals to $10^{-11.2 \pm 0.6} \mathrm{MPa}^{-4} \mathrm{~s}^{-1}$ and $Q$ has a value of $135 \pm$ $15 \mathrm{~kJ} \mathrm{~mol}^{-1}$. Maximum water fugacity was assumed at given pressure and temperature and was computed from the fugacity calculator (https://www.esci.umn.edu/people/researchers/ withe012/fugacity.htm; Pitzer and Sterner, 1994). 


\section{The Supplement related to this article is available online at doi:10.5194/se-8-379-2017-supplement.}

Competing interests. The authors declare that they have no conflict of interest.

Acknowledgements. This research was funded in part by NSF grant EAR-1250128 to John P. Platt. George Rossman, Richard Hervig and Lynda Williams, Raymond Donelick and Margaret Donelick, Rosario Esposito, and Elizabeth Bell are thanked for their help with Raman spectroscopy, ion probe, fission track, electron probe, and cathodoluminescence analysis, respectively. We thank Rüdiger Kilian for handling the manuscript and his valuable comments, and appreciate the constructive reviews from Ruth Keppler and Uwe Ring. Haoran Xia is grateful to Jason Williams, Wenrong Cao and Haiming Tang for their help in the field.

Edited by: R. Kilian

Reviewed by: R. Keppler and U. Ring

\section{References}

Barth, A. P. and Schneiderman, J. S.: A comparison of structures in the Andean orogen of northern Chile and exhumed midcrustal structures in southern California, USA: An analogy in tectonic style?, Int. Geol. Rev., 38, 1075-1085, doi:10.1080/00206819709465383, 1996.

Beaumont, C., Jamieson, R. A., Butler, J. P., and Warren, C. J.: Crustal structure: A key constraint on the mechanism of ultrahigh-pressure rock exhumation, Earth Planet. Sc. Lett., 287, 116129, doi:10.1016/j.epsl.2009.08.001, 2009.

Behr, W. M. and Platt, J. P.: Rheological evolution of a Mediterranean subduction complex, J. Struct. Geol., 54, 136-155, doi:10.1016/j.jsg.2013.07.012, 2013.

Behr, W. M., Thomas, J. B., and Hervig, R. L.: Calibrating Ti concentrations in quartz for SIMS determinations using NIST silicate glasses and application to the TitaniQ geothermobarometer, Am. Mineral., 96, 1100-1106, doi:10.2138/am.2011.3702, 2011.

Berman, R. G.: Internally-consistent thermodynamic data for minerals in the system $\mathrm{Na}_{2} \mathrm{O}-\mathrm{K}_{2} \mathrm{O}-\mathrm{CaO}-\mathrm{MgO}-\mathrm{FeO}$ $\mathrm{Fe}_{2} \mathrm{O}_{3}-\mathrm{Al}_{2} \mathrm{O}_{3}-\mathrm{SiO}_{2}-\mathrm{TiO}_{2}-\mathrm{H}_{2} \mathrm{O}-\mathrm{CO}_{2}$, J. Petrol., 29, 445-522, doi:10.1093/petrology/29.2.445, 1988.

Beyssac, O., Goffé, B., Chopin, C., and Rouzaud, J. N.: Raman spectra of carbonaceous material in metasediments: a new geothermometer, J. Metamorph. Geol., 20, 859-871, doi:10.1046/j.1525-1314.2002.00408.x, 2002.

Brandon, M. T., Roden-Tice, M. K., and Garver, J. I.: Late Cenozoic exhumation of the Cascadia accretionary wedge in the Olympic Mountains, northwest Washington State, Geol. Soc. Am. Bull., 110, 985-1009, doi:10.1130/00167606(1998)110<0985:LCEOTC>2.3.CO;2, 1998.

Brun, J.-P. and Faccenna, C.: Exhumation of high-pressure rocks driven by slab rollback, Earth Planet. Sc. Lett., 272, 1-7, doi:10.1016/j.epsl.2008.02.038, 2008 .

Bukovská, Z., Wirth, R., and Morales, L. F. G.: Pressure solution in rocks: focused ion beam/transmission electron microscopy study on orthogneiss from South Armorican Shear Zone, France, Contrib. Mineral. Petr., 170, 31, doi:10.1007/s00410-015-11868, 2015.

Burchfiel, B. C. and Davis, G. A.: Mojave Desert and environs, in: The geotectonic development of California, edited by: Ernst, W. G., Prentice Hall, Englewood Cliffs, New Jersey, USA, 217-252, 1981.

Chapman, A. D., Kidder, S., Saleeby, J. B., and Ducea, M. N.: Role of extrusion of the Rand and Sierra de Salinas schists in Late Cretaceous extension and rotation of the southern Sierra Nevada and vicinity, Tectonics, 29, 1-21, doi:10.1029/2009TC002597, 2010.

Chapman, J. S. and Melbourne, T. I.: Future Cascadia megathrust rupture delineated by episodic tremor and slip, Geophys. Res. Lett., 36, L22301, doi:10.1029/2009GL040465, 2009.

Cherven, V. B.: A delta-slope-submarine fan model for Maestrichtian part of Great Valley Sequence, Sacramento and San Joaquin basins, California, AAPG Bull., 67, 772-816, doi:10.1306/03B5B6AA-16D1-11D7-8645000102C1865D, 1983.

Cloos, M. and Shreve, R. L.: Subduction-channel model of prism accretion, melange formation, sediment subduction, and subduction erosion at convergent plate margins: 1. Background and description, Pure Appl. Geophys., 128, 455-500, doi:10.1007/BF00874548, 1988.

Coney, P. J. and Reynolds, S. J.: Cordilleran Benioff Zones, Nature, 270, 403-406, doi:10.1038/275464a0, 1977.

Cox, S. F. and Paterson, M. S.: Experimental dissolutionprecipitation creep in quartz aggregates at high temperatures, Geophys. Res. Lett., 18, 1401-1404, doi:10.1029/91GL01802, 1991.

Crowell, J. C.: An outline of the tectonic history of southeastern California, in: The geotectonic development of California, edited by: Ernst, W. G., Prentice Hall, Englewood Cliffs, New Jersey, USA, 583-600, 1981.

DeCelles, P. G.: Late Jurassic to Eocene evolution of the Cordilleran thrust belt and foreland basin system, western USA, Am. J. Sci., 304, 105-168, doi:10.2475/ajs.304.2.105, 2004.

den Brok, S. W. J. (Bas): Effect of microcracking on pressure-solution strain rate: The Gratz grain-boundary model, Geology, 26, 915-918, doi:10.1130/00917613(1998)026<0915:EOMOPS>2.3.CO;2, 1998.

Dibblee, T. W. J.: Areal geology of the western Mojave Desert California, Geol. Surv. Prof. Paper, 522, 1-153, 1967.

Dibblee, T. W. J.: Geologic map of the Crystal Lake quadrangle, Dibblee Geological Foundation Map, Santa Barbara, California, DF-87, 2002a.

Dibblee, T. W. J.: Geologic map of the Glendora quadrangle, Dibblee Geological Foundation Map, Santa Barbara, California, DF89,2002 b.

Dibblee, T. W. J.: Geologic map of the Mount Baldy quadrangle, Dibblee Geological Foundation Map, Santa Barbara, California, DF-90, 2002c.

Dibblee, T. W. J.: Geologic Map of the Mount San Antonio quadrangle, Dibblee Geological Foundation Map, Santa Barbara, California, DF-88, 2002d.

Dickinson, W. R. and Snyder, W. S.: Plate tectonics of the Laramide orogeny, Geol. Soc. Am. Mem., 151, 355-366, 1978. 
Dodson, M. H.: Theory of Cooling Ages, in: Lectures in Isotope Geology, edited by: Jäger, E. and Hunziker, J. C., Springer-Verlag Berlin Heidelberg, Berlin, Germany, 194-202, 1979.

Doubrovine, P. V. and Tarduno, J. A.: A revised kinematic model for the relative motion between Pacific oceanic plates and North America since the Late Cretaceous, J. Geophys. Res., 113, B12101, doi:10.1029/2008JB005585, 2008.

Ehlig, P. L.: Origin and tectonic history of the basement terrane of the San Gabriel Mountains, Central Transverse Ranges, in: The geotectonic development of California, edited by: Ernst, W. G., Prentice Hall, Englewood Cliffs, New Jersey, USA, 253-283, 1981.

England, P. C. and Holland, T. J. B.: Archimedes and the Tauern eclogites: the role of buoyancy in the preservation of exotic eclogite blocks, Earth Planet. Sc. Lett., 44, 287-294, doi:10.1016/0012-821X(79)90177-8, 1979.

Ernst, W. G.: Californian blueschists, subduction, and the significance of tectonostratigraphic terranes, Geology, 12, 436440, doi:10.1130/0091-7613(1984)12<436:CBSATS>2.0.CO;2, 1984.

Ernst, W. G.: Rise and fall of the Nevadaplano, Int. Geol. Rev., 51, 583-588, doi:10.1080/00206810903063315, 2009.

Ernst, W. G., Maruyama, S., and Wallis, S.: Buoyancy-driven, rapid exhumation of ultrahigh-pressure metamorphosed continental crust, P. Natl. Acad. Sci. USA, 94, 9532-9537, doi:10.1073/pnas.94.18.9532, 1997.

Farver, J. and Yund, R.: Silicon diffusion in a natural quartz aggregate: Constraints on solution-transfer diffusion creep, Tectonophysics, 325, 193-205, doi:10.1016/S0040-1951(00)00121-9, 2000.

Fournier, R. O. and Potter, R. W.: An equation correlating the solubility of quartz in water from $25^{\circ}$ to $900^{\circ} \mathrm{C}$ at pressures up to 10000 bars, Geochim. Cosmochim. Ac., 46, 1969-1973, doi:10.1016/0016-7037(82)90135-1, 1982.

Gerya, T. V. and Stockhert, B.: Exhumation rates of high pressure metamorphic rocks in subduction channels: The effect of Rheology, Geophys. Res. Lett., 29, 1261, doi:10.1029/2001GL014307, 2002.

Graham, C. M. and England, P. C.: Thermal regimes and regional metamorphism in the vicinity of overthrust faults: an example of shear heating and inverted metamorphic zonation from southern California, Earth Planet. Sc. Lett., 31, 142-152, doi:10.1016/0012-821X(76)90105-9, 1976.

Graham, C. M. and Powell, R.: A garnet-hornblende geothermometer: calibration, testing, and application to the Pelona Schist, Southern California, J. Metamorph. Geol., 2, 13-31, doi:10.1111/j.1525-1314.1984.tb00282.x, 1984.

Gratz, A. J.: Solution-transfer compaction of quartzites: progress toward a rate law, Geology, 19, 901-904, doi:10.1130/00917613(1991)019<0901:STCOQP>2.3.CO;2, 1991.

Greene, G. W., Kristiansen, K., Meyer, E. E., Boles, J. R., and Israelachvili, J. N.: Role of electrochemical reactions in pressure solution, Geochim. Cosmochim. Ac., 73, 2862-2874, doi:10.1016/j.gca.2009.02.012, 2009.

Grigull, S., Krohe, A., Moos, C., Wassmann, S., and Stöckhert, B.: "Order from chaos": A field-based estimate on bulk rheology of tectonic mélanges formed in subduction zones, Tectonophysics, 568-569, 86-101, doi:10.1016/j.tecto.2011.11.004, 2012.
Grove, M., Jacobson, C. E., Barth, A. P., and Vucic, A.: Temporal and spatial trends of Late Cretaceous - early Tertiary underplating of Pelona and related schist beneath southern California and southwestern Arizona, Geol. S. Am. S., 374, 381-406, doi:10.1130/0-8137-2374-4.381, 2003.

Hamilton, W.: Tectonic setting and variations with depth of some Cretaceous and Cenozoic structural and magmatic systems of the western United States, in: Metamorphism and crustal evolution of the western United States, edited by: Ernst, W. G., Prentice Hall, Englewood Cliffs, New Jersey, USA, 1-40, 1988.

Heald, M. T.: Cementation of Simpson and St. Peter Sandstones in Parts of Oklahoma, Arkansas, and Missouri, J. Geol., 64, 16-30, doi:10.1086/626314, 1956.

Henry, C. D.: Uplift of the Sierra Nevada, California, Geology, 37, 575-576, doi:10.1130/focus062009.1, 2009.

Hirth, G., Teyssier, C., and Dunlap, J.: An evaluation of quartzite flow laws based on comparisons between experimentally and naturally deformed rocks, Int. J. Earth Sci., 90, 77-87, doi:10.1007/s005310000152, 2001.

Holyoke, C. W. and Kronenberg, A. K.: Accurate differential stress measurement using the molten salt cell and solid salt assemblies in the Griggs apparatus with applications to strength, piezometers and rheology, Tectonophysics, 494, 17-31, doi:10.1016/j.tecto.2010.08.001, 2010.

House, M. A., Wernicke, B. P., and Farley, K. A.: Dating topography of the Sierra Nevada, California, using apatite (U-Th)/He ages, Nature, 396, 66-69, doi:10.1038/23926, 1998.

House, M. A., Wernicke, B. P., and Farley, K. A.: Paleogeomorphology of the Sierra Nevada, California, from (U-Th)/He ages in apatite, Am. J. Sci., 301, 77-102, doi:10.2475/ajs.301.2.77, 2001.

Houston, H.: Low friction and fault weakening revealed by rising sensitivity of tremor to tidal stress, Nat. Geosci., 8, 409-415, doi:10.1038/ngeo2419, 2015.

Huang, R. and Audétat, A.: The titanium-in-quartz (TitaniQ) thermobarometer: A critical examination and re-calibration, Geochim. Cosmochim. Ac., 84, 75-89, doi:10.1016/j.gca.2012.01.009, 2012.

Ide, S., Shelly, D. R., and Beroza, G. C.: Mechanism of deep low frequency earthquakes: Further evidence that deep non-volcanic tremor is generated by shear slip on the plate interface, Geophys. Res. Lett., 34, L03308, doi:10.1029/2006GL028890, 2007.

Jacobson, C.: Relationship of deformation and metamorphism of the Pelona Schist to movement on the Vincent thrust, San Gabriel Mountains, southern California, Am. J. Sci., 283, 587-604, 1983a.

Jacobson, C.: Structural geology of the Pelona Schist and Vincent thrust, San Gabriel Mountains, California, Geol. Soc. Am. Bull., 94, 753-767, 1983b.

Jacobson, C.: Qualitative thermobarometry of inverted metamorphism in the Pelona and Rand Schists, southern California, using calciferous amphibole in mafic schist, J. Metamorph. Geol., 13, 79-92, 1995.

Jacobson, C.: Metamorphic convergence of the upper and lower plates of the Vincent thrust, San Gabriel Mountains, southern California, USA, J. Metamorph. Geol., 15, 155-165, 1997.

Jacobson, C., Oyarzabal, F., and Haxel, G.: Subduction and exhumation of the Pelona-Orocopia-Rand schists, southern California, Geology, 24, 547-550, 1996. 
Jacobson, C. E.: Petrological evidence for the development of refolded folds during a single deformational event, J. Struct. Geol., 6, 563-570, doi:10.1016/0191-8141(84)90065-8, 1984.

Jacobson, C. E.: The ${ }^{40} \mathrm{Ar} /{ }^{39} \mathrm{Ar}$ geochronology of the Pelona schist and related rocks, southern California, J. Geophys. Res., 95, 509528, doi:10.1029/JB095iB01p00509, 1990.

Jacobson, C. E. and Dawson, M. R.: Structural and metamorphic evolution of the Orocopia Schist and related rocks, southern California: Evidence for late movement on the Orocopia fault, Tectonics, 14, 933-944, doi:10.1029/95TC01446, 1995.

Jacobson, C. E., Grove, M., Vućić, A., Pedrick, J. N., and Ebert, K. A.: Exhumation of the Orocopia Schist and associated rocks of southeastern California: Relative roles of erosion, synsubduction tectonic denudation, and middle Cenozoic extension, Geol. S. Am. S., 419, 1-37, doi:10.1130/978-0-8137-2419-5, 2007.

Jennings, C. W.: Geologic map of California, California Division of Mines and Geology, Sacramento, California, 1977.

Joesten, R.: Grain growth and grain-boundary diffusion in quartz from the Christmas Mountains (Texas) contact aureole, Am. J. Sci., 283, 233-254, 1983.

Johnson, H. P. and Carlson, R. L.: Variation of sea floor depth with age: A test of models based on drilling results, Geophys. Res. Lett., 19, 1971-1974, doi:10.1029/92GL01946, 1992.

Kidder, S. and Ducea, M. N.: High temperatures and inverted metamorphism in the schist of Sierra de Salinas, California, Earth Planet. Sc. Lett., 241, 422-437, doi:10.1016/j.epsl.2005.11.037, 2006.

Kooser, M.: Stratigraphy and Sedimentology of the type San Francisquito Formation, southern California, Pacific Section SEPM, 22, 53-61, 1982.

Kristiansen, K., Valtiner, M., Greene, G. W., Boles, J. R., and Israelachvili, J. N.: Pressure solution - The importance of the electrochemical surface potentials, Geochim. Cosmochim. Ac., 75, 6882-6892, doi:10.1016/j.gca.2011.09.019, 2011.

Kruhl, J. H.: Reply: Prism- and basal-plane parallel subgrain boundaries in quartz: a microstructural geothermobaromether, J. Metamorph. Geol., 16, 142-146, doi:10.1046/j.15251314.1996.00413.x, 1998.

Law, R. D.: Deformation thermometry based on quartz $c$ axis fabrics and recrystallization microstructures: A review, J. Struct. Geol., 66, 129-161, doi:10.1016/j.jsg.2014.05.023, 2014.

Lee, E., Chen, P., Jordan, T. H., Maechling, P. B., Denolle, M. A. M., and Beroza, G. C.: Full-3-D tomography for crustal structure in Southern California based on the scattering-integral and the adjoint-wavefield methods, J. Geophys. Res.-Sol. Ea., 119, 6421-6451, doi:10.1002/2014JB011346, 2014.

Li, Y.-G., Henyey, T. L., and Silver, L. T.: Aspects of the crustal structure of the western Mojave Desert, California, from seismic reflection and gravity data, J. Geophys. Res., 97, 8805-8816, doi:10.1029/91JB02119, 1992.

Liu, L., Gurnis, M., Seton, M., Saleeby, J., Müller, R. D., and Jackson, J. M.: The role of oceanic plateau subduction in the Laramide orogeny, Nat. Geosci., 3, 353-357, doi:10.1038/ngeo829, 2010.

Massonne, H.-J. and Schreyer, W.: Phengite geobarometry based on the limiting assemblage with K-feldspar, phlogopite, and quartz, Contrib. Mineral. Petr., 96, 212-224, doi:10.1007/BF00375235, 1987.
Meyer, E. E., Greene, G. W., Alcantar, N. A., Israelachvili, J. N., and Boles, J. R.: Experimental investigation of the dissolution of quartz by a muscovite mica surface: Implications for pressure solution, J. Geophys. Res.-Sol. Ea., 111, 2-5, doi:10.1029/2005JB004010, 2006.

Miller, F. and Morton, D.: Comparison of granitic intrusions in the Pelona and Orocopia Schists, southern California, J. Res. US Geol. Surv., 5, 643-649, 1977.

Moore, T. E., O'Sullivan, P. B., Potter, C. J., and Donelick, R. A.: Provenance and detrital zircon geochronologic evolution of lower Brookian foreland basin deposits of the western Brooks Range, Alaska, and implications for early Brookian tectonism, Geosphere, 11, 93-122, doi:10.1130/GES01043.1, 2015.

Müller, R. D., Sdrolias, M., Gaina, C., and Roest, W. R.: Age, spreading rates, and spreading asymmetry of the world's ocean crust, Geochem. Geophy. Geosy., 9, Q04006, doi:10.1029/2007GC001743, 2008.

Oyarzabal, F. R., Jacobson, C. E., and Haxel, G. B.: Extensional reactivation of the Chocolate Mountains subduction thrust in the Gavilan Hills of southeastern California, Tectonics, 16, 650-661, doi:10.1029/97TC01415, 1997.

Paterson, M. S.: A theory for granular flow accommodated by material transfer via an intergranular fluid, Tectonophysics, 245, 135151, doi:10.1016/0040-1951(94)00231-W, 1995.

Pitzer, K. S. and Sterner, S. M.: Equations of state valid continuously from zero to extreme pressures for $\mathrm{H}_{2} \mathrm{O}$ and $\mathrm{CO}_{2}$, J. Chem. Phys., 101, 3111-3116, doi:10.1063/1.467624, 1994.

Platt, J. P.: Dynamics of orogenic wedges and the uplift of high-pressure metamorphic rocks, Geol. Soc. Am. Bull., 97, 1037-1053, doi:10.1130/00167606(1986)97<1037:DOOWAT>2.0.CO;2, 1986.

Porter, R., Zandt, G., and McQuarrie, N.: Pervasive lower-crustal seismic anisotropy in Southern California: Evidence for underplated schists and active tectonics, Lithosphere, 3, 201-220, doi:10.1130/L126.1, 2011.

Raj, R.: Creep in polycrystalline aggregates by matter transport through a liquid phase, J. Geophys. Res., 87, 4731-4739, doi:10.1029/JB087iB06p04731, 1982.

Ring, U., Will, T., Glodny, J., Kumerics, C., Gessner, K., Thomson, S., Güngör, T., Monié, P., Okrusch, M., and Drüppel, K.: Early exhumation of high-pressure rocks in extrusion wedges: Cycladic blueschist unit in the eastern Aegean, Greece, and Turkey, Tectonics, 26, TC2001, doi:10.1029/2005TC001872, 2007.

Ruff, L. J. and Tichelaar, B. W.: What Controls the Seismogenic Plate Interface in Subduction Zones?, in: Geophysical Monograph: American Geophysical Union, edited by: Bebout, G. E., Scholl, D. W., Kirby, S. H., and Platt, J. P., vol. 96, 105-111, American Geophysical Union, Washington, D.C., USA, 1996.

Rutter, E. H. and Elliott, D.: The kinetics of rock deformation by pressure solution [and Discussion], Philos. T. Roy. Soc. A, 283, 203-219, doi:10.1098/rsta.1976.0079, 1976.

Saleeby, J., Ducea, M., and Clemens-Knott, D.: Production and loss of high-density batholithic root, southern Sierra Nevada, California, Tectonics, 22, 1064, doi:10.1029/2002TC001374, 2003.

Shelley, D.: Igneous and metamorphic rocks under the microscope, Chapman and Hall, London, UK, 1993.

Stipp, M. and Tullis, J.: The recrystallized grain size piezometer for quartz, Geophys. Res. Lett., 30, 2088, doi:10.1029/2003GL018444, 2003. 
Stipp, M., Tullis, J., and Behrens, H.: Effect of water on the dislocation creep microstructure and flow stress of quartz and implications for the recrystallized grain size piezometer, J. Geophys. Res., 111, B04201, doi:10.1029/2005JB003852, 2006.

Stipp, M., Tullis, J., Scherwath, M., and Behrmann, J. H.: A new perspective on paleopiezometry: Dynamically recrystallized grain size distributions indicate mechanism changes, Geology, 38, 759-762, doi:10.1130/G31162.1, 2010.

Stöckhert, B.: Stress and deformation in subduction zones: insight from the record of exhumed metamorphic rocks, Geol. Soc. Lond. S. P., 200, 255-274, doi:10.1144/GSL.SP.2001.200.01.15, 2002.

Tagami, T., Ito, H., and Nishimura, S.: Thermal annealing characteristics of spontaneous fission tracks in zircon, Chem. Geol., 80, 159-169, doi:10.1016/0168-9622(90)90024-7, 1990.

Terres, R. R. and Luyendyk, B. P.: Neogene tectonic rotation of the San Gabriel Region, California, suggested by paleomagnetic vectors, J. Geophys. Res., 90, 12467-12484, doi:10.1029/JB090iB14p12467, 1985.

Thomas, J. B., Watson, E. B., Spear, F. S., Shemella, P. T., Nayak, S. K., and Lanzirotti, A.: TitaniQ under pressure: the effect of pressure and temperature on the solubility of $\mathrm{Ti}$ in quartz, Contrib. Mineral. Petr., 160, 743-759, doi:10.1007/s00410-010-0505-3, 2010.

Thomas, J. B., Watson, E. B., Spear, F. S., and Wark, D. A.: TitaniQ recrystallized: experimental confirmation of the original Ti-in-quartz calibrations, Contrib. Mineral. Petr., 169, 27, doi:10.1007/s00410-015-1120-0, 2015.

Turcotte, D. L. and Schubert, G.: Geodynamics, 2nd ed., Cambridge University Press, Cambridge, UK, 2002.

Vallier, T. L., Dean, W. E., Rea, D. K., and Thiede, J.: Geologic evolution of Hess Rise, central North Pacific Ocean, Geol. Soc. Am. Bull., 94, 1289-1307, doi:10.1130/00167606(1983)94<1289:GEOHRC>2.0.CO;2, 1983.
Wark, D. A. and Watson, E. B.: TitaniQ: a titanium-inquartz geothermometer, Contrib. Mineral. Petr., 152, 743-754, doi:10.1007/s00410-006-0132-1, 2006.

Wassmann, S. and Stöckhert, B.: Rheology of the plate interface - Dissolution precipitation creep in high pressure metamorphic rocks, Tectonophysics, 608, 1-29, doi:10.1016/j.tecto.2013.09.030, 2013.

Watson, E. B. and Wark, D. A.: Diffusion of dissolved $\mathrm{SiO}_{2}$ in $\mathrm{H}_{2} \mathrm{O}$ at $1 \mathrm{GPa}$, with implications for mass transport in the crust and upper mantle, Contrib. Mineral. Petr., 130, 66-80, doi:10.1007/s004100050350, 1997.

Wernicke, B., Clayton, R., Ducea, M., Jones, C. H., Park, S., Ruppert, S., Saleeby, J., Snow, J. K., Squires, L., Fliedner, M., Jiracek, G., Keller, R., Klemperer, S., Luetgert, J., Malin, P., Miller, K., Mooney, W., Oliver, H., and Phinney, R.: Origin of High Mountains in the Continents: The Southern Sierra Nevada, Science, 271, 190-193, doi:10.1126/science.271.5246.190, 1996.

Weyl, P. K.: Pressure solution and the force of crystallization: a phenomenological theory, J. Geophys. Res., 64, 2001-2025, doi:10.1029/JZ064i011p02001, 1959.

Xia, H. and Platt, J. P.: Is the Vincent fault in southern California the Laramide subduction zone megathrust?, in preparation, 2017.

Yin, A.: Passive-roof thrust model for the emplacement of the Pelona-Orocopia Schist in southern California, United States, Geology, 30, 183-186, doi:10.1130/00917613(2002)030<0183:PRTMFT>2.0.CO;2, 2002.

Zaun, P. E. and Wagner, G. A.: Fission-track stability in zircons under geological conditions, Nucl. Tracks Rad. Meas., 10, 303307, doi:10.1016/0735-245X(85)90119-X, 1985. 